\title{
The Rise and Fall of the Booster Ethos in Dubuque, 1850-1861
}

\author{
TIMOTHY R. MAHONEY
}

ON THE AFTERNOON of July 18, 1855, the citizens of Dubuque, Iowa, and "distinguished" railroad excursionists from across the region gathered at a "barbeque picnic" on a hill above town to celebrate the completion of the Illinois Central Railroad to Dunleith, Illinois, the town just across the river from Dubuque. The picnic was the culminating event of a "railroad festival" to mark the "new birthday" of their "beloved city of the mines." Boosters proclaimed that Dubuque, having become the western terminus of the system, stood at a critical moment in its history. Now was the time for all citizens to put aside their differences to implement a booster policy that would make Dubuque the great emporium and metropolis of the Northwest. ${ }^{1}$

Like boosters across the urban West in the mid-1850s, Dubuque's leaders understood that the approach of the railroad altered the dynamics of regional development and thus raised the stakes in the competition among towns for regional hegemony. As a result, boosters intensified their efforts to exhort townspeople to support a booster system of improvement and railroad companies working together with city government to promote town development. As the cost of these efforts outstripped

1. Dubuque Express and Herald, 13, 14, 17, 18, 19, 20, 22, and 27 July 1855; Robert

F. Klein, ed., Dubuque: Frontier River City (Dubuque, 1984), 130-34; George Nightingale to George Wallace Jones, 15 May 1856, George Wallace Jones Papers, State Historical Society of Iowa, Des Moines.

THE ANNALS OF IOWA 61 (Fall 2002). C The State Historical Society of Iowa, 2002. 
private and local resources, however, it became increasingly clear that public funding would be needed. So boosters broadened their rhetoric. Instead of arguing on the basis of mere economic self-interest, they began to tie urban development to a social and cultural vision of their town's future. If townspeople would unite behind booster policy based on their common interests, the boosters argued, they could create a self-sufficient regional urban center that would promote prosperity and harmony for all townspeople. Enthralled by this ideology, townspeople across the region opened public coffers and transformed boosters into a social and cultural oligarchy that sought to order and control local life. In doing so between 1856 and 1860, they put town unity to the test-particularly in the wake of the Panic of 1857-and unwittingly undermined the booster system and the towns they had worked so hard to promote. ${ }^{2}$

In Dubuque as elsewhere, the town boosters' credentials for leadership were well established. Many were among the "early settlers" who had participated in local government, politics, and the legal system. They had founded associations, institutions, and churches while developing a downtown business culture. Meanwhile, many boosters had cultivated middle-class gentility to establish a secure social position. In the course of navigating between their private social lives and public interactions in the course of their everyday business activities, they had learned how to employ the discourse and behaviors of gentility and collective sociability among lawyers, businessmen, and members of a broader male subculture to suppress conflict and break down entrenched private social, political, and cultural interests and attitudes within various groups in town. Now, as boosters articulating a social vision, they sought to fuse elements of middle-class gentility, the downtown business culture, and local immigrant subcultures into a unified booster ethos that would

2. Carl Abbott, "Boosterism," Encyclopedia of Urban America, 2 vols. (Santa Barbara, CA, 1998), 1:89-90; idem, Boosters and Businessmen: Popular Economic Thought and Urban Growth in the Antebellum Middle West (Wesport, CT, 1981); David Hamer, New Towns in the New World: Images and Perceptions of the Nineteenth-Century Urban Frontier (New York, 1990); Robin Einhorn, Property Rules: Political Economy in Chicago, 1833-1872 (Chicago, 1991), 28-60; Robert H. Wiebe, The Opening of American Society (New York, 1984), 290. 
support the "booster system." ${ }^{3}$ Their success would depend on how well the key representatives of a town's predominant subcultures-"genteel society," the male subculture of politics and Main Street, and immigrant culture-were able to ease tensions, work together, and promote unity. ${ }^{4}$ Representing these subcultures in Dubuque were, respectively, the Langworthy brothers, George Wallace Jones, and Richard Bonson.

AS THE "FOUNDING FATHERS" of Dubuque, the Langworthys were the foundation of Dubuque's "good society." They were so much "identified with the history of Dubuque" that their biographies were, as one county history claimed, "the history of our city." James, Edward, and Lucius Langworthy, who began mining in the area even before it was opened for settlement in 1833, were among the "first settlers" to arrive at Dubuque. A fourth brother, Solon, joined them in 1834. Striking rich lodes of lead in Couler valley, the Langworthy brothers quickly gained control of mining and smelting in town. In 1836 the brothers pooled their resources and formed a partnership, James L. Langworthy and Brothers. The company operated mines and smelting furnaces up Langworthy Hollow and the Maquoketa Little Creek valley and ran a land agency, mercantile emporium, and bank on lower Main Street. By the mid-1850s the Langworthys "owned ... the most valuable lands in and about the city." As bankers, they carefully chose their loans and investments, dealt only in specie, and were "not much obliged to

3. Timothy R. Mahoney, Provincial Lives: Middle Class Experience in the Antebellum Middle West (New York, 1999). This discussion draws from and contributes to a debate about the nature of political and social interaction within an emerging public sphere in nineteenth-century American cities and towns. See Philip J. Ethington, The Public City: The Political Construction of Urban Life in San Francisco, 1850-1900 (New York, 1994); Mary P. Ryan, Civic Wars: Democracy and Public Life in the American City during the Nineteenth Century (Berkeley, CA, 1997); and Glenn C. Altschuler and Stuart M. Blumin, Rude Republic: Americans and Their Politics in the Nineteenth Century (Princeton, NJ, 2000).

4. Timothy R. Mahoney, "'A Common Band of Brotherhood': The Booster Ethos, Male Subcultures, and the Origins of Urban Social Order in the Midwest of the 1840s," Journal of Urban History 25 (1999), 619-46.

5. C. C. Childs, The History of Dubuque County, Iowa (Chicago, 1880), 830; Lucius $\mathrm{H}$. Langworthy to George Wallace Jones, 4 January 1855, George Wallace Jones Papers. 


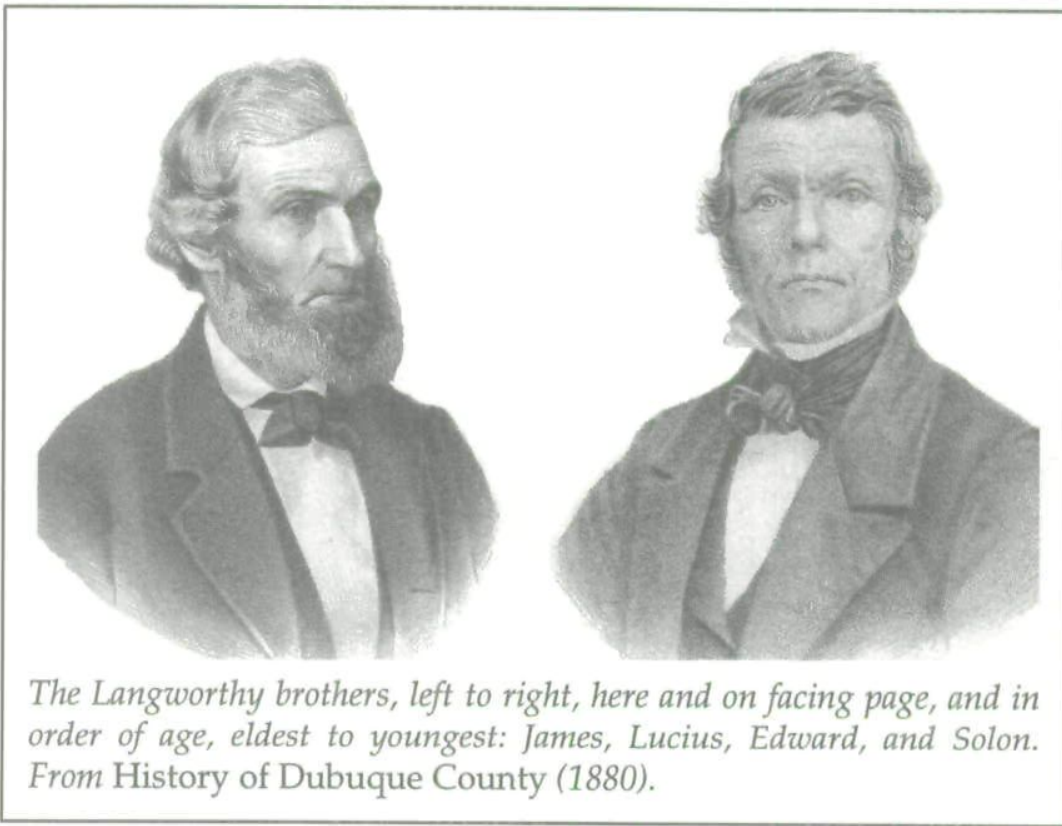

anybody." In 1856 the Langworthys were the richest men in town, each worth a few million dollars in today's terms, paying together about one-twelfth of the town's taxes.

Not surprisingly, the Langworthys developed a proprietary relationship with the townspeople. Often viewing Dubuque as their town, they considered their interests as identical with the city's. The Langworthys were among the settlers who founded the town of Dubuque, laid out the town plat, purchased and sold real estate, and improved numerous streets in town in 1834. Later they invested in steamboats and ferries to enhance their mercantile trade and Dubuque's role as a mercantile center. As men "of foresight [they] were keenly alive to everything which could build up a city," and "as "citizen[s]" were "ever open to aid the material prosperity of Dubuque." They were generous

6. "Autobiographical Sketch of Solon M. Langworthy," Iowa Journal of History and Politics 8 (1910), 335; Iowa Credit Report Ledger 31, R. G. Dun and Company Collection, Baker Library, Harvard Graduate School of Business Administration, Cambridge, MA; William Franklin Langworthy, comp., The Langworthy Family: Some Descendants of Andrew and Rachel Langworthy (Hamilton, NY, 1940), 262. 


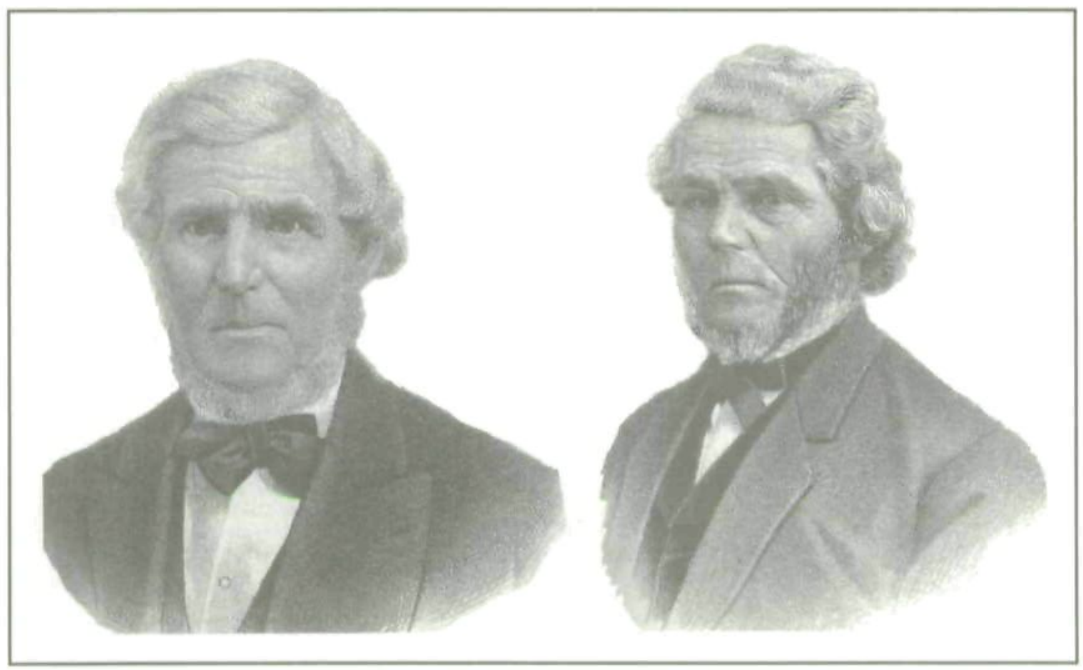

"friends of schools and churches" and were involved in building the first school in Iowa. Their sense of civic duty drew the Langworthys into public service. Lucius served as the county's first sheriff and stood up to the ruffian "border society" in the young mining settlement. James helped establish the first rules regarding mining claims in 1830, and in the 1840s served on the committee that administered the transfer of lands from the government into private hands. Edward served as town trustee in 1838 and three times as alderman. In general, though, the Langworthys preferred to exert influence as private citizens and boosters. $^{\text {? }}$

The Langworthys stood at the center of a group of early settlers who sought to align their interests with those of the town. Both Lucius and Edward became active and prominent boosters. They made speeches, wrote articles, and published pamphlets admonishing townspeople to formulate policies that would make their town a "future metropolis," a new "Athens of the West," and "the pride of the Mississippi valley." Throughout their lives in Dubuque, the Langworthys had far more resources at their disposal than the town did. Thus they were called upon regularly to support public activities. In some ways, the Lang-

7. Childs, History of Dubuque County, 828, 831. 
worthys became a proprietary shadow government behind the official elected powers, using their own "means and credit" to build the city. ${ }^{8}$

Yet the Langworthys were somewhat reluctant to exert influence within the emerging booster ethos. Their wealth in lead mining and land declined in value after the lead mining industry peaked and then declined in the 1840s. This limited their ability to raise capital or attract outside capital to town and intensified their desire to rely on their own resources. Politically, the Langworthys stood independently outside the local Democratic political culture. Socially, the four brothers and their families sequestered themselves in a small set within the town's genteel society that others might emulate but relatively few could enter. The Langworthy houses, built in a cluster outside of town in the 1840 s and above the town on the bluffs in the 1850s, reflected an aloof, proprietary sense of entitlement and noblesse oblige. On "Langworthy Bluff," they created in the 1850s a private "Langworthy society" to which only a select set of genteel residents gained access through a restricted system of calls, teas, and parties. Given their narrow set of social relations, the Langworthys' influence in the affairs of elite churches, societies, associations, and institutions was limited. Likewise, the Langworthys lacked access via the male subculture or the adjacent culture of the bench and bar to broader social and political influence. This circumscribed their ability to promote unity and speak for the public good. ${ }^{9}$

TWO MILES WEST of Langworthy Bluff, in a village settled in the 1830 s by immigrants from Swaledale, Yorkshire, Richard Bonson lived in a world defined by its opposition to the Lang-

8. Lucius H. Langworthy, "Dubuque: Its History, Mines, Indian Legends, Etc.," Iowa Journal of History and Politics 8 (1910), 422; Childs, History of Dubuque County, 828.

9. Solon Langworthy, Diary, 12 January 1861, State Historical Society of Iowa, Iowa City; Dubuque Weekly Tribune, 3 July 1850; Carl H. Johnson, Heritage of Dubuque: An Architectural View (Dubuque, 1975), 19-20; David Singal, "Modernist Culture in America: Introduction," American Quarterly 39 (1987), 7-25; Richard L. Bushman, The Refinement of America: Persons, Houses, Cities (New York, 1992), 406-13, 319-35; Mahoney, Provincial Lives, 131-34, 163-67. 
worthy society. Bonson and a handful of Yorkshire men had followed the Langworthys from southwestern Wisconsin to Dubuque. Recognizing the advantage the Langworthys had acquired in Langworthy Hollow, Bonson staked his fortune in the Catfish Creek valley to the south of the village. In competition with the Langworthys, Bonson expanded and improved his blast furnace. Increasingly he acquired lead from fellow Yorkshire miners scattered across the region. By the early 1840s, Bonson had purchased or claimed more than 40 tracts in the region. Later, he extended his domain further south. He established a smelter at Lockey Drybone and Pike's Peak mines, two of his richest lodes. He also purchased a cluster of mining lots to the north near the rich Karrick, Bartlett, McKenzie, Stewart, and Burton "lodes" or "diggings," each owned by other Yorkshire men, including John Burton, his father-in-law. This economic system, connected to the outside through Bonson's furnaces, and anchored socially at Center Grove, a community of a few hundred clustered on the low ground near the headwater of the Middle Fork of Catfish Creek, existed independently and separately from the Langworthys' economic system. ${ }^{10}$

Richard Bonson reinforced his autonomy from the marketplace economy through a combination of self-sufficient and limited cash crop farming. His farmhouse, built in 1853 on the hill north of Center Grove, was the center of a network of several other farms that Bonson worked or rented out to tenant farmers. The production of the farms supported his and other families. He supplemented his income with wheat sales to the Catfish Mills in Rockdale. Bonson structured a neighborhood economy by trading and bartering goods and produce with merchants, other farmers, tenants, and farm hands to settle obligations, pay rent, and buy and sell land. By 1850, as recorded in his remarkable diary, Bonson had settled into a regular round of excursions to various diggings and smelters in the Catfish Creek district, operating and managing his home and outlying farms, going to Center Grove Methodist Church to worship on Sundays, visiting relations and friends in the neighborhood, and regularly going

10. "Autobiographical Sketch of Solon Langworthy," 335; Childs, History of Dubuque County, 464, 400; Deed Index, Dubuque County, Dubuque County Courthouse, Dubuque; Plat Book of Dubuque County, Iowa (Philadelphia, 1892). 
down the road from Center Grove into lower Dubuque to attend to real estate matters at the Dubuque County Courthouse.

Even though Bonson aspired to self-sufficiency, much of his world, like that of the Langworthys and other miners, was still driven by the logic of the marketplace. Given the scale of their operations, he and the Langworthys were among the few to survive the shakeout in the mining industry from the late $1830 \mathrm{~s}$ through the mid-1840s. Bonson joined the Langworthys on the Mining Claims Settlement Committee that transferred public mineral lots into private hands when the federal government finally released for sale more than five hundred mineral lots west of Dubuque. Many of those lots were interspersed across Bonson's and other Yorkshire men's holdings. As they acquired additional lots, they gained an advantage over the Langworthys. Like the Langworthys, however, Bonson was squeezed by higher production costs, declining volume, and uncertain prices at the primary market in St. Louis. Thus, Bonson engaged in mining and smelting only "in intervals" in the 1850s when prices were particularly high. As he found it more and more difficult to justify operating, Bonson, like the Langworthys, watched the foundation of his fortune erode. Recognizing that he "must be doing something" else, Bonson, who unlike the Langworthys was not involved in land speculation, banking, and merchandising, retreated to farming, a self-sufficient world of tangible wealth. ${ }^{11}$

Although Bonson's world was separate from the market economy centered on Main Street and grounded by the Langworthys, both he and the Langworthys recognized that the decline in mining threatened to undermine Dubuque's and their own economic futures. In their attempts to align personal and community self-interest, both were drawn into the booster ethos. While the Langworthys' aloofness, anchored by their private

11. Timothy R. Mahoney, River Towns in the Great West: The Structure of Provincial Urbanization in the American Midwest, 1820-1870 (New York, 1990), 198-200; Loren N. Horton, ed., The Character of the Country: The Iowa Diary of James L. Broderick, 1876-1877 (Iowa City, 1976), 120-21; Childs, History of Dubuque County, 462-64, 529; Richard Bonson, Diary, 1 January 1857, State Historical Society of Iowa, Iowa City (original at Center for Dubuque Area History, Loras College, Dubuque). Most of the interpretation of Richard Bonson's life is drawn from a close analysis of his diary. 


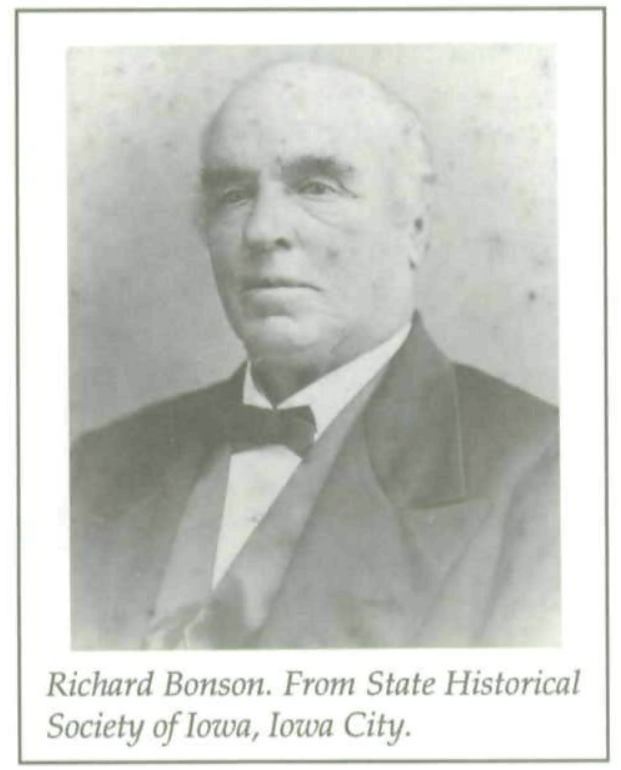

family-centered social sphere, held them back, Bonson's unhappy personal life, which undermined his social position as patriarch of his family and leader in the immigrant community, would push him into boosterism indirectly through politics. Bonson's "unpleasant family affaires" [sic] resulted from an unhappy marriage to Jane Burton. Bonson's house, instead of a haven of genteel comfort, was a wasteland of recrimination and discord. Proud and independent, Bonson was too ashamed to "open his mind to anyone on the subject." Instead, he took refuge in an office that he rented on Fourth Street around the corner from Main Street. There he ran his operations and became increasingly involved in the public social life of lower Main Street. Yet his moderate temperance views limited his interactions with boosters who socialized within the male subculture of the town, while his married "bachelor" status prevented him from entering Dubuque's genteel "social circles."1

Nevertheless, Bonson was gradually drawn into politics through his associations with members of the Democratic Party. But he entered the Langworthys' economy and society reluc-

12. Bonson, Diary, 6 August 1856, 9 February 1852. 
tantly. He stood firm in his belief in a political economy of autonomous actors, unfettered by government policies or restraints of any kind, investing their own capital without incurring debt, securing contracts with a shake of the hand, and exchanging goods and services for cash or short-term notes among acquaintances. To Bonson, patronage, nepotism, and personal arrangements, rather than creating potential conflicts of interest, insured economic actions by friendship, mutual trust, and self-interest.

FOR BONSON, and to a lesser extent the Langworthys, the path into the booster ethos lay through the realm of local politics and the adjacent culture of the bench and bar. In Dubuque, the power broker at the intersection of these two realms was George Wallace Jones. From his arrival in 1836, two years after Bonson and the Langworthys, Jones had been a core member of the "fathers of the bar" elite that shaped the structure of the local bench and bar and dominated Dubuque's Democratic Party. Although he did not practice much law, Jones, as a Democratic Party member, was part of a powerful group that also included Stephen Hempstead, Warner Lewis, Thomas S. Wilson, and Peter Engle. That group controlled most of the town's litigation and regularly received appointments to judicial or public office. Jones was also an influential member of the "old guard" who controlled entrance to the local bar by selectively sponsoring newcomers, distributing cases, and structuring partnerships. ${ }^{13}$ Known as "the General," Jones was skilled in cultivating camaraderie and fraternity. When he was home during court terms or recesses from Congress, he participated in "mock debates" and "moot tribunals," and threw "awfully fashionable parties," "levees," and "dances" where lively conversation, singing, roustabouting, "indulg[ing] . . . freely" in the "flowing bowl," and even "frolics" were often the order of the evening. Like other bar members, he also gave and attended "blow-outs," "oyster suppers," banquets, and excursions to celebrate his col- 


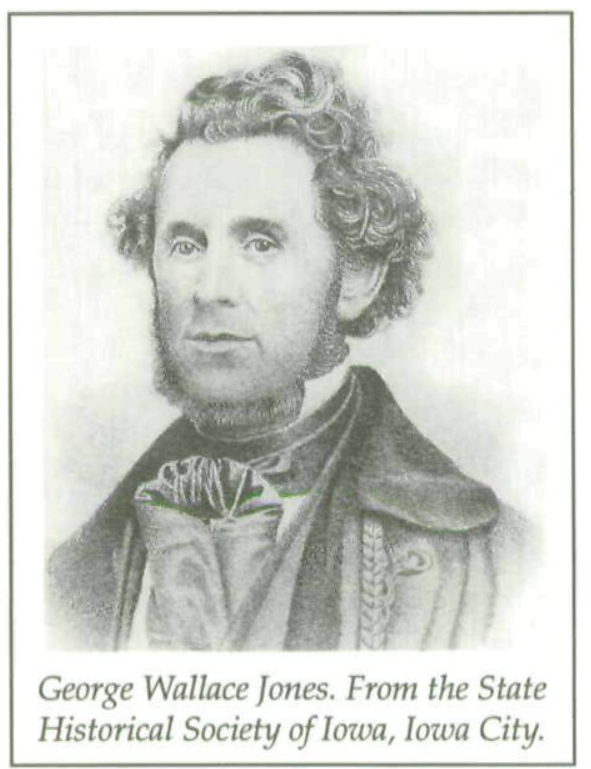

leagues' achievements. Such events cultivated impartial professional behavior as well as solidarity and civility among men one knew personally but against whom one competed intensely. Through such close interactions, members of the core group of town lawyers and judges forged deep friendships and, as "brethren of the bar," became a "sort of a family to itself." ${ }^{14}$

For Jones, of course, such involvement was also politics. Because members of the bar formed a pool of skill and knowledge that provided Dubuque and northeastern Iowa with its political leadership for a generation, Jones understood that in predominantly Democratic Dubuque, the course of town politics-and the cliques and factions within the party-was shaped by interactions among members of the local bar. Jones's appointments as territorial judge in 1833 and then as territorial delegate to Congress in 1835 enabled him to build a power base by giving him access to patronage in territorial offices, which he distributed to "friends" and associates who supported him. He almost ended his public career in 1838 by serving as a second in the

14. Lincoln Clark to Julia Clark, 21 February 1855, Lincoln Clark Papers, Huntington Library, San Marino, CA; Stiles, Recollections and Sketches, 255, 17; History of Adams County, Illinois (Chicago, 1879), 416; Mahoney, Provincial Lives, 207-11. 
infamous duel between William J. Graves and Jonathan Cilley in Washington, D.C., but patronage saved him: in 1841 his "friends" repaid his efforts on their behalf by getting him an appointment as clerk of the territorial court. Jones used this position to reenter politics and, through his efforts to keep the General Land Office in Dubuque, acquired sufficient claim to the office to be appointed surveyor general in 1845, from which he acquired the title "General" Jones. Fearing a Whig victory in 1848 would end his tenure as surveyor general, Jones ran for and was elected U.S. Senator, defeating fellow Dubuque bar member and former Iowa Supreme Court Justice Thomas S. Wilson by a single vote in the state legislature. ${ }^{15}$

For twelve years, Dubuque politics was shaped by Jones's efforts to control local patronage. He reinforced his use of patronage with an aggressive social agenda and the sheer force of his personality. The "Chesterfield gentleman" of the Senate and Washington society, Jones established himself in Dubuque as the "the mark and model" of local society by building a "princely residence" along Julien Avenue on the hill above the town in 1847. Invitations to dinners and soirees at Jones's house were much sought after. Attendance at his levees or open houses-where Jones, "full of flattery, buncombe, and stories," "facile courtesy," and excessive "bowing and scraping" prevailed as the "pet of women" and the "idol of men"- was required for his supporters. Jones viewed politics as a continual negotiation and exchange among male political "friends." $\mathrm{He}$ worked tirelessly for his friends and expected them to do so for him with unquestioned loyalty. ${ }^{16}$ But his supporters were more than mere "friends;" they were "Jones men" or, as his oppo-

15. John C. Parish, George Wallace Jones (Iowa City, 1912), 157-70, 31-35; Andreas, Illustrated Historical Atlas of Iowa, 365.

16. Stiles, Recollections and Sketches, 96; Augustus L. Chetlain, Recollection of Seventy Years (Galena, 1899), 38; Parish, George Wallace Jones, vii, 32; Virginia Clay-Clopton, A Belle of the Fifties: Memoirs of Mrs. Clay of Alabama, Covering Social and Political Life in Washington and the South, 1853-66 (New York, 1905), 80-81; Josiah Conzett, "My Recollections of Dubuque, Iowa, 1846 to 1890," 268, State Historical Society of Iowa, Iowa City; Jane Taylor to John Taylor, 7 December 1857, John W. Taylor Collection, New-York Historical Society, New York City; Robert Wiebe, "Lincoln's Fraternal Democracy," in John L. Thomas, ed., Abraham Lincoln and the American Political Tradition (Amherst, MA, 1986), 19-21. 


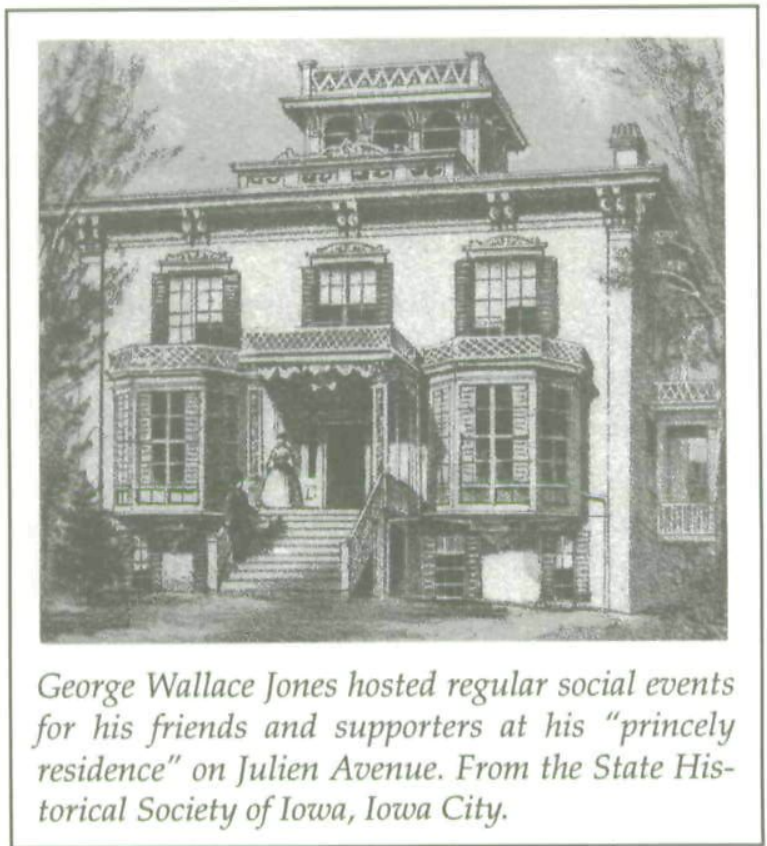

nents charged, "Jones' tool[s]" or "sycophants." At least one of his supporters went so far as to name a son after him. It is fair to say that Jones's supporters surrendered their political and social autonomy in return for personal loyalty to the man who gave them a political identity and career. ${ }^{17}$

Almost every local Democrat's career was shaped by the nature of his relationship with Jones. The careers of Thomas Rogers, William Barney, Caleb Booth, Warner Lewis, Ben Samuels, John J. Dyer, Lincoln Clark, and Richard Bonson were supported by Jones's political tactics and shaped by the rise and fall of his power. ${ }^{18}$ Those who remained loyal rose and fell with

17. John J. Dyer to George Wallace Jones, 21 March 1850, George Wallace Jones Papers; Lincoln Clark to Julia Clark, 15 December 1852, 3 January and 5 April 1853, Lincoln Clark Papers; Parish, George Wallace Jones, 280.

18. Andreas, Illustrated Historical Atlas of Iowa, 366; Stiles, Recollections and Sketches, 819, 415, 824, 161-63; William J. Barney, Diary, 6, 8, 18, 19, 23, 26, and 31 January and 24 and 27 February 1846, State Historical Society of Iowa, Iowa City; W. J. Barney to GWJ, 21 February 1849, George Wallace Jones Papers; Childs, History of Dubuque County, 838; Richard Bonson, Diary, 1-25 December $1852,1,7$, and 8 October 1853. 
Jones. Those who steered a more independent course or opposed Jones moved in the opposite direction. Invariably, the independent-minded, while treated cordially by Jones in public, were exiled from Jones's circle and denied access to political office or party influence.

Over the years, "exiles" gradually coalesced into an opposition faction. Judge Thomas S. Wilson became Jones's first opponent when he stood against Jones for the U.S. Senate in 1848 and came within one vote of defeating him. That event set off a longstanding bitter personal enmity and prompted the emergence of a Wilson faction that worked hard to defeat Jones in the elections of 1852 and 1858. As the political feud intensified, the opposing factions hardened and added key recruits. The independent Stephen Hempstead and Thomas Rogers would join Wilson's faction; and Dennis Mahony and Joseph B. Dorr founded the Dubuque Express and Herald "for the purpose . . of fighting Jones." ${ }^{19}$

Jones's power in this contest is illustrated by the short-lived career of Lincoln Clark, a New England lawyer who arrived in Dubuque in 1847 by way of Alabama. Jones quickly took Clark under his wing, choosing his "friend" as U.S. congressman from the Dubuque district in 1850. At first Clark enjoyed the benefits of his new status as a Jones insider: invitations to parties, levees, strategy meetings, and political caucuses "behind the curtain where great men relaxed." Jones also sent Clark a flood of reports, books, and papers to educate him. Eventually, however, Clark, a proud man, bristled at his dependency. When he publicly opposed a railroad bill proposed by Jones, Jones cut Clark off completely, withdrew his support, portrayed him as a supporter of his opponent Thomas Wilson, and ended his career. Clark returned home a year later, humiliated and mortified. Placed under the "ban of oligarchy," he knew he was "finished" politically. $^{20}$

19. Parish, George Wallace Jones, 34, 180-82, 44-46; M. M. Hoffman, "The Wilsons of Dubuque," Annals of Iowa 21 (1935), 237.

20. Lincoln Clark to Julia Clark, 31 January, 10, 13, and 25 February, 5 and 21 July 1852, 3 January, 28 February, and 17 March 1853, Lincoln Clark Papers; Franc Wilkie, A Brief Sketch of the Life and Services and a Defence [sic] of the Public 
Richard Bonson had more success balancing an independent course and loyalty to Jones. Like Clark, Bonson got his start in politics as a "Jones man" and made quick gains because of Jones's initial influence. Jones set up a reluctant Bonson as state legislator from Dubuque County in 1852. Less concerned than Clark about the appearance of dependency, Bonson enjoyed being with other "Jones men" such as John G. Shields, Judge John King, Ben Samuels, William J. Barney, George Nightingale, John J. Dyer, George Williams, Judge William Lovell, Richard Mobley, Charles Corkery, Thomas McKnight, and Patrick Quigley. ${ }^{2}$

Thus Bonson, as a representative of Dubuque's immigrant culture, interacted with the Main Street culture of the bench and bar, led by George Wallace Jones; and both were conscious of the dominant presence of the genteel culture headed by the Langworthys. Through politics, as well as by forming associations, clubs, churches, and other institutions, the interests and identities of the men involved in Dubuque's three distinct elite subcultures intersected, allowing the town's pioneer entrepreneurs to establish and promote a common booster ethos.

AT FIRST, Dubuque's booster policy and state and national politics were linked. The early booster elite more or less ran Dubuque's city government in the 1840 s and early 1850 s. In addition to the Langworthys, that group included a small coterie of boosters from the Main Street elite: Jesse P. Farley, a pioneer merchant and three-time mayor; Caleb H. Booth, Dubuque's first mayor, who was also involved in lumber milling, mining, and the land warrant business with William J. Barney; Peter A. Lorimier, a miner, smelter, and merchant; Major Richard Mobley, Dubuque's first and most prominent banker; plus a number of Democratic lawyers and politicians, such as Warner Lewis, George Nightingale, John Shields, and David S. Wilson. ${ }^{22}$ Early boosters acted on the premise that city government was a "tool

Course of Hon. George Wallace Jones, United States Senator from the State of Iowa (n.p. 1852), 31-32.

21. Richard Bonson, Diary, 1-25 December 1852, 1, 7, and 8 October 1853.

22. Childs, History of Dubuque County, 786-87, 838, 850, 881; Andreas, Illustrated Historical Atlas of Iowa, 366-68; Childs, Frontier River City, 74, 81, 91. 
to promote growth and commerce." The miners among Dubuque boosters focused their attention in the 1840s on gaining control of federally owned lead-mining lands and improving their city's harbor to enable Dubuque to compete with Galena as a shipper of lead to St. Louis. ${ }^{23}$ Requiring legislation and financial support from the federal government, both efforts brought Jones's influence to bear on local affairs and connected local efforts to the formulation of national policy. ${ }^{24}$

Jones's involvement in booster affairs intensified when boosters across the Midwest ran into strong opposition in Washington to the idea of the government undertaking or funding internal improvements. Such opposition was typically voiced by Democrats, at least until Jones and other western Democrats called for a change in public policy. Although they failed to convince the federal government to pursue harbor and river improvements, the shift in focus to railroads in the late 1840 s renewed the debate.

But the emergence of the corporation as a new organizational framework to build railroads, a necessity given the vast cost of the undertaking, reoriented the debate. Across the Midwest, private corporations were chartered to undertake railroad projects: the Galena and Chicago Union Railroad in 1846; the Alton and Chicago Railroad in 1847; and the Northern Cross Railroad in 1848. Jones himself called meetings in Dubuque to encourage local boosters to buy stock in the Galena and Chicago Union Railroad. Soon thereafter he organized his own company, the Keokuk and Dubuque Railroad, to build a southnorth railroad. The organizational benefits of the corporation were obvious: concentrated management in a board of directors, limited liability to directors and stockholders, and access to

23. Einhorn, Property Rules, 44; Childs, Frontier River City, 67.

24. Childs, Frontier River City, 69, 73; Mentor Williams, "The Background of the Chicago River and Harbor Convention, 1847," Mid-America 30 (1948), 223; Resolutions of the Legislature of Iowa, Relative to the Completion of the Harbor at Dubuque, January 25, 1849, 30th Cong., 2d sess., House Misc. Doc. 14; Portion of town plan of both Dubuque and Dunleith, Illinois, 33d Cong., 2d sess., Senate Ex. Doc. No. 1, 1854; Jefferson Davis, Report of the Secretary of War, In compliance with a Resolution of the Senate of the 28th ultimo, the Report of W. R. Palmer, Respecting the Improvement of the Harbor of Dubuque, March 3, 1857, 34th Cong., 3d sess., Senate Exec. Doc. 66, 1857. 
vast private capital without any need to consult local or state government. Yet corporations continued to have trouble securing enough working capital. They also encountered legal resistance to private entities operating on such a broad scale. Such issues brought the debate back to government. ${ }^{25}$

The Illinois Central Railroad Bill, presented to Congress in 1850 by Illinois Senator Stephen Douglas, turned the debate in a new direction. Jones's involvement intensified, and the booster ethos in Dubuque was transformed. The proposed federal government grant of public lands to a private corporation-in this case the Illinois Central Railroad-was defended on the grounds that the grant, by enabling the company to build the railroad, would serve the "public good." The act thus transformed corporations into quasi-public entities. Passed in 1850, the bill established a precedent that capitalists and entrepreneurs across the West rushed to follow. As "railroad fever" swept across Illinois and eastern Iowa, Jones ensured that Dubuque would catch the "fever." At the last moment, he asked Senator Douglas to add an amendment to the bill to extend construction to the Mississippi River opposite Dubuque, thus making Dubuque rather than Galena the terminus of the Illinois Central. Recognizing that a connection to the Mississippi River would strengthen the argument that the bill served a "national interest," Douglas agreed, apparently without taking into consideration the response of Galena boosters. Dubuque residents were immediately aware of the implications as Jones's "stock ... advance[d] one hundred percent" and his "enemies ha[d] nothing left them." ${ }^{26}$

Dubuque boosterism and national politics would coincide from the passage of the Illinois Central Bill in 1850 to the passage of an Iowa Land Grant Bill in 1856. However, local support for Jones's north-south Keokuk and Dubuque Railroad was un-

25. William B. Ogden to Charles S. Hempstead, 31 July, 1849, Charles S. Hempstead Papers, Chicago Historical Society; Childs, Frontier River City, 77; Parish, George Wallace Jones, 36-37, 41-42; Alan Trachtenberg, The Incorporation of America: Culture and Society in the Gilded Age (New York, 1982), 4, 6-7; Mason Brayman Papers, Chicago Historical Society.

26. Parish, George Wallace Jones, 38; Robert W. Johannsen, Stephen A. Douglas (New York, 1973), 310-12; Hobart C. Carr, Early History of Iowa Railroads (New York, 1981), 39, 53-55; J. J. Norman to George Wallace Jones, 17 February 1850, George Wallace Jones Papers. 
dermined by the Illinois Central Bill and by the founding of the Chicago and Rock Island Railroad in Davenport in 1851, the Burlington and Missouri River Railroad in 1851, and the Peoria and Oquawka Railroad in Burlington in 1852. Some locals, such as Lincoln Clark, argued that Dubuque should build a road running west from Dubuque. Jones suggested, however, that Iowans supporting each of the competing railroads-including his own, which ran perpendicular to (and thus literally at cross purposes with) the other newly proposed railroads-join forces to advocate a variety of land grants crisscrossing the state in the "national interest." In the spring of 1852, boosters from Burlington, Davenport, Dubuque, and even Keokuk rushed to Washington, D.C., to lobby for the Iowa Land Grant Bill in Congress. Because the contradictory plan reflected local jealousies rooted in obvious local interests, they were unable to argue convincingly that the grant fulfilled a "national" interest. They also faced strong opposition from supporters of Galena. Harsh criticism from Thompson Campbell, Galena's U.S. congressman, touched off an emotional debate that highlighted the local, rather than national, interests behind the bill. As a result, the Iowa railroad bill failed to pass. ${ }^{27}$

THE FAILURE of the initial effort to acquire a land grant had three immediate consequences: it finished Jones's Keokuk and Dubuque Railroad; it focused Jones's and other Dubuque boosters' attention on securing the promised connection to the Illinois Central; and it convinced some Dubuque boosters that they needed to organize their own railroad company and secure from Congress a land grant extending to the west. ${ }^{28}$ Dubuque boosters pursued the first part of this new strategy by courting Illinois Central officials with offers of land and capital to ensure construction of the railroad to Dunleith, Illinois. They also invited railroad officials to visit Dubuque.

27. Childs, Frontier River City, 77-78; Mahoney, Provincial Lives, 236-39.

28. Lincoln Clark to Julia Clark, 6 June 1852, Lincoln Clark Papers; Childs, Frontier River City, 78; Thomas S. Nairn to George Wallace Jones, 9 January 1851, George Wallace Jones Papers. 
Meanwhile, Dubuque boosters worked to thwart renewed efforts by Galena boosters to repeal Jones's amendment to the Illinois Central Bill. Dubuque boosters observed with satisfaction-and some trepidation-the Illinois Central's determination to crush Galena boosters' resistance to "the corporate behemoth." Perhaps taken aback by this display of corporate power over local interests such as their own, Dubuque boosters proceeded to form their own railroad company. ${ }^{29}$

In April and early May 1853 Dubuque boosters called a series of railroad meetings to organize a railroad company. George Wallace Jones and his "old friend" Lucius Langworthy enthralled those in attendance with visions of Dubuque as the eastern terminus of a road that stretched across Iowa and then Nebraska Territory, through the South Pass of the Rockies to San Francisco. In spite of a vigorous debate about the political and economic feasibility of such a company, the Dubuque and Pacific Railroad Company was chartered on May 16, 1853, under Iowa's Articles of Incorporation. Jones, two outside investors, and some of Dubuque's most committed boosters-Lucius Langworthy, H. W. Sanford (land speculator), Jesse P. Farley (then mayor of Dubuque), F. S. Jesup, Robert Waller (a friend of Richard Bonson), and Platt Smith - were appointed to the board. Smith, a lawyer, was elected to organize and run the company. ${ }^{30}$

Dubuque boosters were determined to maintain local control over the Dubuque and Pacific Company. This set them apart from boosters in Davenport and Burlington. There, Chicagoans and New Yorkers were granted majority control of the Chicago and Rock Island Railroad, the Burlington and Missouri River Railroad, and, somewhat later, the Peoria and Oquawka. Per-

29. This story is told in the Mason Brayman Papers, general correspondence, June 1852-August 1854, Chicago Historical Society. See also Charles Hempstead Papers, Chicago Historical Society; Mahoney, Provincial Lives, 218-39; and the following letters in New York Office, In-Letters, Illinois Central Collection, Newberry Library, Chicago: Henry S. Wiltse and William Y. Lovell to Robert Schuyler, March 1851; H. W. Sanford to Robert Schuyler, 21 August 1851; Citizens of Galena, Petition to Change Terminus of the Road to Galena, 16 April 1852; Nicholas Dowling to Robert Schuyler, 5 June 1852; H. W. Sanford to George Wallace Jones, 29 May 1852; and George Wallace Jones to Illinois Central Railroad Board of Directors, June 1852.

30. Childs, Frontier River City, 111. 
haps Dubuque boosters' frustrations about government control of mining lands or their awareness of the vagaries of the marketplace explains their commitment to maintaining ownership and control over local economic development. Or perhaps the scale of their efforts and doubts that the river would be bridged at Dubuque protected them. In any case, they imagined Dubuque as a mostly locally owned regional economic center run by and for the benefit of all townspeople. Committed to defending this ideology of the "way of the town," a hallmark of what would later be called the "old middle class," they bristled at the thought of their town becoming just an outpost or stop along a road controlled by outsiders. Hence, the efforts of the directors of the Dubuque and Pacific Railroad, from its establishment in 1853 through its reorganization in 1864 and its subsequent demise in the late 1870 s, to maintain control became a symbolic struggle of local resistance against national economic forces. ${ }^{31}$

The firm's local agenda, however, made it difficult for many Dubuquers to view it as anything more than a particular selfinterested group of investors, as opposed to a coalition of individuals representing a broad public interest. Platt Smith would quickly discover this when he launched a three-pronged strategy to acquire capital from townspeople to build the first 30 miles of the line, putting the company in a position to be able to fulfill the obligations of a federal land grant. First he passed the hat among the directors and received promises for $\$ 500,000$. Then he "got up the stock subscriptions" among the people of Dubuque and surrounding counties. Smith knew, however, that stock subscriptions and promises to pay often took months to generate cash, and neither would bring in enough to meet the exorbitant cost of railroad construction. Therefore, he resuscitated an old idea once tried to support harbor improvements: he asked the city and county governments for public funds. Smith proposed that the city and county kick off the stock subscription drive by buying $\$ 100,000$ and $\$ 200,000$ of railroad stock, respectively, with public funds. Before others could question the

31. Wiebe, The Opening of American Society, 299; Platt Smith to C. B. Raymond, 25 January 1858, Dubuque and Pacific Railroad Company, Dubuque Office, Out-Letters, 1856-1861, Illinois Central Railroad Collection, Newberry Library; Report of the Dubuque and Pacific Railroad Company (Dubuque, 1858), 19. 
move, Smith asked the mayor (a railroad director) to formally ask the county judge (a friend of the railroad) to call for an election to vote on a public referendum on the question. He then launched a campaign of public meetings with "great talk about a railroad to the Pacific." Not surprisingly, voters approved the proposal by a 5 to 1 ratio in town and 4 to 3 in the county. Concluding that Dubuquers had decided that "we are [now] a railroad people," Smith rented an office on Main Street, printed up letterhead, and got down to the work of being a "railroad man."

Although he was successful in gaining an electoral majority, Smith's request for public funds unwittingly interjected the Dubuque and Pacific's business strategy into a divisive political debate on public policy that undermined boosters' efforts to foster unity. This was particularly troublesome because, until a land grant bill was almost assured, Smith was unable to use evidence of construction progress to rally support behind the railroad. Nor, Smith gradually realized, could he depend as much as he had on George Wallace Jones to unify Dubuque Democrats behind the railroad. It was apparent that Jones's political power had reached its apex. The fallout from the failed effort to acquire a land grant in 1852, the perception that Jones was serving his last term in the U.S. Senate, the passage of the Kansas-Nebraska Act, and the rise of the Republican party (Iowa elected a Republican governor in 1854) weakened Jones's control over the party and invigorated a variety of factions. The rising power of other Democrats, Whigs, and Republicans interjected a new dynamic into booster affairs. As the suppressed political ambitions of others, including Richard Bonson and the Langworthys, were given new life, their commitment to act for the public good and support a booster policy weakened.

OPPOSITION to the Dubuque and Pacific Railroad's agenda came quickly. A group of longtime opponents of George Wallace Jones, led by David S. Wilson and James Burt, filed a lawsuit

32. Andreas, Illustrated Historical Atlas of Iowa, 367; Dubuque County v. Dubuque and Pacific Railroad, 4 Greene 6; Richard Bonson, Diary, 19 May and 4 and 6 June 1853; Platt Smith to Jesse P. Farley, 23 August 1857, Dubuque and Pacific Railroad, Illinois Central Collection. 
against the railroad in Dubuque district court. They charged that state law prohibited the city and county, just like the state government, from holding stock in private corporations. By issuing bonds to buy railroad stock, the city and county were allowing a majority to illegally tax a minority.

Platt Smith successfully defended the railroad in both the district and state supreme courts. He argued that since the constitution permitted counties and cities to issue bonds for extraordinarily costly bridge and road projects and, because railroads were, by implication, "roads," such a use of public funds was legal. By sanctioning the use of public funds to pursue boosters' goals, Dubuque County v. Dubuque and Pacific Railroad turned the corporation into a quasi-public-policy-making entity. The ruling transformed the political economy in towns and cities across Iowa and further west. The promise of public funding gave life to a variety of companies and intertwined booster policy and local politics. ${ }^{33}$

More opposition came from within the board of directors. In a discussion about where to locate the depot and what route the road should take west out of Dubuque, the north-south split among mining interests quickly surfaced. On one side, Richard Bonson, Richard Waller, J. Emerson, and probably H. W. Sanford advocated that the depot be located downtown near lower Main Street, with the line proceeding west via Couler valley and Catfish Creek valley, where they owned land. On the other side, Lucius Langworthy, Jesse P. Farley, and others argued for a depot uptown, with tracks going west out through Langworthy Hollow. Dennis A. Mahony, editor of the Dubuque Express and Herald, rebuked the directors for "split[ting] up into selfish cliques and coteries" and for acting for their own self-interest without regard for the "interests of the people." But neither Mahony's public criticism, the hastily organized railroad festival to celebrate the arrival of the Illinois Central Railroad across

33. Dubuque County v. Dubuque and Pacific Railroad, 4 Greene 6; Michael A. Ross, "Cases of Shattered Dreams: Justice Samuel Freeman Miller and the Rise and Fall of a Mississippi River Town," Annals of Iowa 57 (1998), 213-15, 230-39; Dubuque and Pacific Railroad Report, 1857; Alan Trachtenberg, The Incorporation of America, 4. 
the river, nor the formation of a Board of Trade could mediate the directors' differences. ${ }^{34}$

Shortly thereafter, Lucius Langworthy resigned from the Dubuque and Pacific board. Then, to force the railroad depot matter, he formed a land company and petitioned the city council to grant city land at Seventh Street to either the Dubuque and Pacific Railroad Company or the Dubuque and Western Railroad Company, which he intended to establish. Responding to a request from an ad hoc people's committee formed to agitate the depot issue, the new Board of Trade tried to draw the sides together by calling for u series of public meetings. The meetings, however, backfired by only deepening the antipathy between the two sides. Supporters of the Dubuque and Pacific Railroad faction opposed Langworthy's petition on the grounds that such a grant did not, like a railroad grant, provide public advantage, and thus would increase public debt solely for private gain. The Langworthys, irked by the criticism, ignored further mediation by the Board of Trade. On September 10, 1855, they formalized their opposition to the Dubuque and Pacific Railroad by incorporating the Dubuque and Western Railroad Company. Although local papers took the formation of another railroad company as evidence that Dubuque was now a true railroad city, the Dubuque and Pacific saw the Langworthys' railroad as a threat and rushed to begin construction-with the help of yet another loan from the city. ${ }^{35}$

Meanwhile, as progress was made in pursuit of an Iowa land grant bill, local land values began to rise. Boosters rushed to buy land in the city around the proposed depot sites of the two railroads, and then established land companies that paralleled the support for the two roads. In May 1855, James, Lucius, and Solon Langworthy incorporated the Dubuque Harbor Improvement Company, or the Seventh Street Company. In response, Richard Bonson, Jesse P. Farley, and several "friends" associated with the Dubuque and Pacific Railroad began buying

34. Childs, Frontier River City, 118; Dubuque Express and Herald, 7 June and 6 and 10 July 1855.

35. Dubuque Express and Herald, 26 and 27 July, 7 August, and 3 and 10 September 1855; City Council Minutes, 18 August 1855, October 1855, Wahlert Memorial Library, Loras College, Dubuque; Childs, Frontier River City, 135-38. 
land around Jones Street in order to dredge the harbor, fill in sloughs, extend streets, and make improvements. They became informally known as the Jones Street Improvement Company. In January 1856 they met to formally incorporate themselves as the Dubuque Harbor Company. The directors included Charles Gregoire, brother-in-law of George Wallace Jones, and two members of the Dubuque and Pacific Railroad board; other directors were stockholders of the Dubuque and Pacific Railroad, including both associates of the Jones faction and Yorkshire friends of Richard Bonson. With even the cautious Bonson convinced that "the Harbor Improvement will make a great deal of money," the inside call for a subscription drew a rush of investors, including George Wallace Jones and many other "Jones men." All of them watched in amazement as shares soared in value in anticipation of the passage of the Iowa land grant bill that would essentially capitalize the Dubuque and Pacific Railroad and secure Dubuque's future. In between the two opposing companies, a third company, the Dubuque Central Improvement Company, run by Robert Waples, Jesse Farley, and Franklin V. Goodrich, each of whom had interest in the Langworthys' company, began to operate informally in early 1856 and was incorporated in July $1857 .^{36}$

Thus by early 1856, as land values appreciated, three sets of booster companies with competing but interlocking directorates and stockholders stood poised to secure public lands and funds from the city council, the state of Iowa, and the federal government. They also sought public and private monies through stock subscriptions in order to make public improvements that would further appreciate the value of lands held privately by their respective companies, as well as by individual directors of each company. With the profits generated, the directors would become rich, and through reinvested capital and prosperity,

36. Dubuque Express and Herald, 25 August 1855; City Council Minutes, 1 July 1855; Childs, Frontier River City, 158; History of Dubuque County, 532; Dubuque County Incorporation Records, County Recorder's Office, Dubuque County Courthouse, Dubuque; "Articles of Incorporation," 2 January 1856, and Minutes, Board of Directors, Dubuque Harbor Company, 1 April, 1856, State Historical Society of Iowa, Iowa City; Richard Bonson, Diary, 1 January 1856; Thomas S. Wilson to George Wallace Jones, 4 March 1856, George Wallace Jones Papers. 
more railroads would be built and more improvements made. Such a "liberal" "railroad policy," which "encourage[d] the construction of roads in every possible direction," would secure for Dubuque "a trade that will in time be as important and valuable to us as was that of the whole North-West to St. Louis," making the former "city of the mines," the great "market" of the region.

THIS BOOSTER POLICY OR SCHEME was firmly rooted in the premise that local boosters would pay for it and control it. Its success hinged on two things. Boosters, organized in companies intricately intertwined by conflicts of interest and personal connections, had to clarify the interaction among various companies and the city government, gain popular support, and muffle local opposition. But first they had to secure passage of the Iowa Land Grant Bill. Without it the scheme was doomed. Rising land prices were the yeast that would make the whole structure expand and generate profits. Having learned from their experience in 1852, as well as from attending several recent regional railroad conventions, that they needed to speak the language of "national interest" to convince out-of-state congressmen to vote for a federal land grant, George Wallace Jones and others made the final push for the passage of a federal land grant for Iowa in the spring of 1856.

But by then the national and regional political climate had changed. The completion of three railroads to the Mississippi, combined with the beginning of construction west of the river, had created a growing bipartisan, albeit sectional, consensus among northern Democrats and Republicans in support of using public land grants to fund the building of a transcontinental railroad. This broadened support for a land grant bill. That winter in Washington, James Thorington of Davenport and George Wallace Jones submitted to the House and Senate respectively bills that would give the state of Iowa four grants of land to be used to fund railroad construction stretching across Iowa. The Burlington and Missouri Railroad, which citizens had subscribed for only on April 7, 1856, would begin in Burlington; the Missis- 
sippi and Missouri Railroad in Davenport; the Cedar Rapids and Missouri Railroad in Lyons; and the Dubuque and Pacific Railroad in Dubuque. Construction of all four lines was to proceed westward to points on the Missouri River. After much less debate than in 1852, the bills passed the House and Senate. On hearing the news in May 1856, Dubuque lawyer George Nightingale wrote to his friend George Wallace Jones, "we feel here in Dubuque that your untiring vigilance in our interests has made us what we are and what we expect to be." As a result of Jones's efforts, he continued, "things look brighter for our beloved 'city of the mines,' every day add[ing] to our importance, wealth, and improvement." ${ }^{\prime 38}$

Six weeks later, the debate shifted from Washington to the Iowa statehouse. Almost everyone expected the special session of the Iowa legislature to accept the federal Iowa Land Grant Bill. Governor James Grimes, however, first wanted to clarify which companies would receive the land grants and upon what terms. Iowans and Dubuquers were divided on those issues. Jones's power was still sufficient to ensure that Dubuque and Pacific supporters, such as Richard Bonson, dominated the Dubuque delegation. In a last-ditch effort, however, the Langworthys tried to disturb the unity of the delegation. A group of Galenans also sought to disrupt the proceedings from the gallery, but the Dubuque delegation quashed their effort.

Meanwhile, supporters back home staved off a rearguard challenge by the Langworthys. After most Dubuque and Pacific supporters had left for Iowa City, the Langworthys called a public meeting "to discuss the railroad interests of Dubuque." At the local meeting, Lucius H. Langworthy, director of the Dubuque and Western Railroad, presented a resolution to run the federally funded line from a depot on Fourth or Fifth Street out through Langworthy Hollow. Major Mobley, speaking for the Dubuque and Pacific, argued that citizens had already effectively chosen the Dubuque and Pacific route. He expressed confidence that the board would act in the "agricultural, manufacturing, and commercial and social interests of northern Iowa."

38. Parish, George Wallace Jones, 48-49; Charles Mason, Diary, 6 April 1856; George Nightingale to George Wallace Jones, 15 May 1856, George Wallace Jones Papers. 
The meeting voted to reject Langworthy's resolution, and the bill in the state legislature passed after a brief debate, thus opening the way for the Dubuque and Pacific to begin construction. ${ }^{39}$

Most Dubuque residents rejoiced at the passage of the bill, but the task of clarifying local arrangements and muffling local dissent still remained. Concerned that the "public good" was being sacrificed for private gain, local populists charged in the Dubuque Herald and Express that the Dubuque Harbor Company and other "piratical companies" "threatened to rule the city" and destroy "existing interests" through "broken promises and violated compacts." The company's directors demanded to know who was responsible for this "base slander," but to no avail. In mid-May, the Dubuque and Pacific Railroad responded by increasing its board to 13 members and stipulating that one of the new directors be a representative of the city and county. Dennis Mahony, editor of the Dubuque Express and Herald, expressed outrage that the directors were trying to deprive the city and county-who owned a majority of the stock-of "all voice and control in the management of the road." In response, the city stipulated that any company that received a grant from the city had to permit an agent of the city to examine their books regularly to determine if they were indeed using public funds "solely for the purpose of construction." ${ }^{40}$

The city government did still possess real power. It owned tracts of "public land" along the river acquired from the federal government a decade before. It could generate revenues from property and sales taxes. And it could call elections. Thus it maintained the critical power to capitalize the railroad and harbor improvement companies by floating public bond issues, contracting out work in return for grants of city-owned land to the companies, as well as simply granting or selling land. The city - as mediator, watchdog, and a source of capital-was the linchpin of the booster system. The various improvement and

39. William Salter, The Life of James W. Grimes (New York, 1876), 80-82; Dubuque Express and Herald, 1 and 11 July 1856.

40. Dubuque Express and Herald, 21 March and 24 May 1856; Richard Bonson, Diary, 25 March 1856; Minutes, Board of Directors, Dubuque Harbor Company, 25 March 1856; Minutes, Dubuque City Council, 15 October 1855. 
railroad companies issued bonds to support improvement and construction projects and contracted with the city to improve city lands near those held privately by the companies. In return, the city would grant the land to the company outright, or the companies would purchase the land for cash or company bonds with a mortgage on company land as collateral. In addition, of course, the companies paid taxes on the land.

As city policy and the operations of private companies became even more elaborately intertwined, everyone in town became more interdependent. As more residents equated private and public interest, more funds funneled into the booster system. In the expansionary environment of 1856, each element of this booster system rapidly took on a heavy burden of debt: the city government to support the railroads; the railroads to build (now made more urgent by the land grant stipulation that they must complete 75 miles of track by December 1, 1859, and 30 miles each year after that for five years); and the land companies to buy land and make improvements. As long as land values rose, city revenues would benefit from increased taxes, continued land sales would generate revenues to help build the railroad, and higher profits would help retire private indebtedness while encouraging all involved to accrue new debt to deepen their investments to meet the ever-expanding needs of a growing metropolis. Interwoven by overlapping directorates with numerous conflicts of interest, this booster system of railroads, improvement companies, and government attracted capital that stoked an upward spiral of speculation and appreciating land values. Boosters in Dubuque rightly believed that the entire future history of the city was at stake. ${ }^{41}$

All through the summer and fall of 1856, in the midst of the boom, anything seemed possible. Driven by ever-rising land prices, investors went into debt to local banks to buy land and stocks and bonds that would be sold again for a quick profit. Instead of using profits to retire debt, investors took on ever more debt to buy more land and stocks. Many individuals, the Langworthys included, purchased or built new houses. Other

41. Exhibits and Documents Relating to the Dubuque and Pacific Railroad Company (New York, 1857), Appendix D; Mahoney; Provincial Lives, 245. 
capitalists floated debts to build new banks, hotels, and business blocks. In downtown Dubuque, 163 buildings were finished or under construction in 1856. The core of the city was essentially rebuilt. Major Mobley built a new two-story bank building on Main Street. Robert Waples "bought up all the land and house[s] he could-pay[ing] but very little cash down." Businessmen expanded their operations. Even the cautious Richard Bonson borrowed heavily from Major Mobley to stimulate his mining business and at year's end "was ten thousand better off than I was one year ago." The Dubuque and Pacific Railroad went into debt to hire the lawyers and engineers who would determine the road's route through the county. Then the railroad hired contractors, builders, and common laborers. Finally, there were supplies: the iron and wood needed to build the road. Along the proposed route, the various improvement companies would fill in and improve lots. With all this activity, Dubuque rode atop a remarkable boom in 1856, and its population soared to more than 15,000. An excited Lincoln Clark, former congressman and now a "railroad man," wrote to his daughter, promising to keep her "informed of the rise and progress of our western Gotham! $!^{\prime 42}$

THE BOOM did not last, however. No sooner had most Dubuque businessmen gone into debt to foster economic development than financial rumblings in the East shook the foundations of Dubuque's booster system. Early in 1857 the price of railroad stocks leveled off and then began to drop. Eastern banks tightened credit, cut off new loans to the West, called in debts, and began to limit the western currency they would accept in payment for obligations. By mid-spring, the credit squeeze had begun to draw specie from the West to the East, leaving western economies with only rapidly depreciating currency. Inflation soared, money supplies shrank, and land and stock prices plummeted. Land sales stopped. Companies and individual

42. Childs, Frontier River City, 149-50, 155; History of Dubuque County, 530; Conzett, "My Recollections of Dubuque," 249, 261; Richard Bonson, Diary, 1 January 1857; Lincoln Clark to Catherine Clark, 29 December 1856, Lincoln Clark Papers. 
investors alike found themselves with unmarketable depreciated assets, no revenue, and heavy debts. ${ }^{43}$

By late spring 1857, the pressure in the East threatened to bring down the entire edifice of the booster system-the railroad and improvement companies as well as the banks, businessmen, and local government that supported them. As local bankers felt pressure to meet obligations back east, they called in loans from individuals who were forced to pursue those who owed them or liquidate depreciated assets, if they could, in order to pay. Thousands of individuals and businesses faced bankruptcy. They delayed liquidation by promising to pay from their remaining assets even as interest on outstanding debts and taxes due on land or housing continued to bury them deeper in debt. As taxes went unpaid, soon even the city government was starved of revenue and unable to pay its employees. The relative simplicity of the chain of debt that tied Dubuquers to each other and to national capital markets thus enabled the pressure to strike with alarming speed at the pillars of the local booster system-the Dubuque and Pacific Railroad and the Dubuque Harbor Company. Again the future of the city was at stake. This time, however, the option was not whether or not Dubuque would become the emporium of the northwest, but whether it would survive at all.

By early July 1857, Platt Smith recognized that the Dubuque and Pacific Railroad Company urgently needed an infusion of funds to allow it to continue to meet its obligations and avoid default. Earlier he and the local directors had allowed two New York investors on the board as trustees. Their purpose was to sell Dubuque and Pacific bonds in the New York and European capital markets. News of poor bond sales in New York and Europe left Smith with only two options. He could go back to the New York trustees for help and risk losing local control of the company, or he could go back to the beleaguered local directors. He decided to go to New York. During his desperate and frustrating two-month-long trip, the financial pressure turned into panic with the collapse of the Ohio Life and Trust Company. Smith despaired about saving the railroad company's credit. The trustees,

43. History of Dubuque County, 531; Dubuque Express and Herald, 27 May 1857; Robert Benson to Abraham Hewitt, 5 and 10 July, and Platt Smith to J. H Colton, March 1858, Dubuque and Pacific Railroad Company, Dubuque Office, In-Letters. 
strapped themselves, were indifferent, inaccessible, and unwilling to lend a hand. To Smith, their blasé attitude about the company's impending failure indicated a willingness to let it fail so they could pick up what was left of the company and run it themselves. Infuriated and deeply aware of how his own, the company's, and Dubuque's self-interest were now intertwined, Smith pondered the consequences of such a course for Dubuque:

What is to be done? ... Our road can be sold on execution if we do not meet our liabilities.... In the meantime property and business in Dubuque will drop and languish-our fine new hotel will remain vacant-improvement companies must stop-the sales they have made will fall through, one line of daily boats will do the business done by two.... the property of Dubuque which is now assessed at ten millions will not be worth five. Businessmen will fail. ... the railroad will . . . fail . . . in a few days unless relief comes immediately. Dubuque will be set back ten years and will probably never recover. ${ }^{4}$

The only solution Smith saw was for the Dubuque directors to save the company and Dubuque by averting, delaying, or putting off liquidation. There were only two ways to do this: go into their own pockets to come up with more working capital, or find a way to liquefy their remaining assets that would allow them to stay in business by temporarily satisfying creditors. Smith desperately called on the "manly vital interests" of Dubuque's boosters to save the "enterprise" from being "ruined." Privately he told J. P. Farley that not to "come to the rescue" would be the "most foolhardy and unmitigated piece of stupidity and want of foresight that was ever heard of." He warned that if the directors did not, he would wash his hands of the whole matter, and "hope in that event the place will sink," as he believed it certainly would. ${ }^{45}$

In September Caleb Booth and Platt Smith undertook a twopronged strategy. First they approached the directors, as well as local banks and the Dubuque Harbor Company, for more contri-

44. Robert Benson to Abraham Hewitt, 5 and 10 July 1857, and Platt Smith to J. P. Farley, 24 and 25 July and 1 and 31 August 1857, Dubuque and Pacific Railroad Company, In-Letters; Minutes, Dubuque City Council, 15 June 1857.

45. Platt Smith to J. P. Farley, 21 and 31 August 1857, Dubuque and Pacific Railroad Company, In-Letters. 
butions for a subscription of stock. Since H. L. Stout and Dickey Waller, members of the board of the Harbor Company, and Richard Bonson, a major stockholder, were, like others, also stockholders in the Dubuque and Pacific Railroad and had railroad bonds among their assets, the Harbor Company felt compelled to agree. Smith raised more capital by using the company's only assets-stock, bonds, and land-as collateral to issue more bonds. Aware how impossible the "money famine" made it for anyone to buy goods and services or pay creditors, Smith decided to issue Dubuque and Pacific Company certificates-in effect, IOUs - to pay workers, contractors, and creditors. He hoped the certificates would circulate as currency with no pressure of redemption on the company. But no sooner had he undertaken these first steps than another wave of pressure hit. When people stopped accepting company certificates, and as promises to buy stock and bonds went unfulfilled, the company found itself back where it started. Richard Bonson remarked that he had "never new [sic] so tight times for money." Facing increasing public pressure, Smith had no choice but to go to the banks-not to ask for loans, but to try to mortgage what he could from railroad and even his personal property to stay afloat. $^{46}$ When even the banks hesitated, Smith played the only card he had left.

Most Dubuquers considered the Dubuque Harbor Company -on the basis of its land holdings, capital improvements, capital assets contributed by its directors, stocks and bonds, and minimal debt-to be "very wealthy"; sounder, in fact, than most banks in town. Indeed, several weaker banks had already failed, and Major Mobley's bank tottered on the brink of failure. The Langworthys, cautious as ever, protected themselves by limiting the currency they would accept, curtailing any further loans, and renegotiating their limited obligations in New York. Their actions tightened the vise on the local economy. With nowhere else to

46. Minutes, Board of Directors, Dubuque Harbor Company, 5 September 1857; Richard Bonson, Diary, 5 September, 9 October, and 23 November 1857; Platt Smith to Jesse Farley, 27 and 29 September and 26 October 1857, Dubuque and Pacific Railroad Company, In-Letters; "Source Material of Iowa History: Mahony-Smith Letters on the Dubuque \& Pacific Railroad, 1857," Iowa Journal of History 54 (1956), 335-60. 
turn, Smith approached the Harbor Company on October 19 to ask for a major loan, offering a mortgage on railroad lands as collateral. He intended to use the loan to issue more bonds and a railroad currency to enable the company to continue operating. Reacting to Smith's proposal, Richard Bonson and some members of the board expressed concerns that currency issued by the railroad would not be able to sustain its value. They feared that the loan would never be repaid and that the failure of the railroad could drag down the Harbor Company with it. As a precaution, they asked permission to check the railroad's books. ${ }^{47}$

Liquidity remained the core of the local economy's predicament. More and more local businesses tried to survive by giving IOUs. The local newspapers did so for a while but found that few people would accept them except for a ring of close associates and friends in the booster system, among whom the IOUs circulated like a transferable personal note or bill of exchange. Devoid of cash like everyone else, the city issued IOUs as a kind of city scrip that they paid to workers and creditors, hoping the scrip would circulate until the city could redeem them with cash. But cash-strapped city workers started selling the city scrip at a discount and then petitioned the city to make up the difference, causing the scrip to fall in value to only about fifty cents on the dollar. When the city's efforts to sustain the scrip's value - either by funneling it through city banks or by issuing treasury notes on the city's good name-came to nothing, it was clear that the city, like most local banks, lacked the people's confidence to sustain the value of its scrip. Even so, the city continued to issue "city scrip" in payment to city workers for another year. ${ }^{48}$

47. Platt Smith to John Duncombe, 26 October 1857, Dubuque and Pacific Railroad Company, In-Letters; Iowa Credit Report Ledger 31, R. G. Dun and Company Collection; Minutes, Board of Directors, Dubuque Harbor Company, 5 September and 19 and 22 October 1857; Richard Bonson, Diary, 5 September, 9, 12, 14, 15, 16, 19, 21, 23, 24, and 31 October, and 23 November 1857.

48. See the following Petitions to City Council in Proceedings, Dubuque City Council, Wahlert Library, Loras College: H. A. Jordan, 4 August 1857; Street Commissioner's Men, 10 August 1857; John Hurley, 16 October 1857; and Berry and Plater, October 1857. See also Minutes, Dubuque City Council, 29 September, 26 October, and 19 November 1857. 
Only scrip issued by a sound company that people trusted would maintain its value and relieve some of the liquidation pressure. Local bankers knew that, except for the Langworthys, none of them had sufficient collateral to issue currency to relieve the local "money famine." Recognizing this, "near all the bankers" of Dubuque (except the Langworthys, who refused to issue bank notes) approached the Dubuque Harbor Company on October 14, 1857, to ask it to issue paper money. In a series of tumultuous meetings, the members of the board-including Richard Bonson, who opposed the idea-debated how to respond to the "application of bankers and resolutions of a meeting of citizens and business men asking of this company the issue of their post notes to relieve the wants of our business." Aware of the risks but also aware that without some currency to meet obligations they too would be foreclosed upon, the desperate directors passed a resolution agreeing that they would "issue notes in sums of 1 to 10 dollars payable one year from date at office of company and that they will loan their credit on securities to their satisfaction ... from $\$ 1$ to $\$ 500,000$ as in their judgement they may be justified and at a rate of interest not exceeding ten percent per annum to be paid in advance." The Dubuque Harbor Company-with no loans from the East or reliance on bond sales, but with assets of cash on hand, land, and stocks and bonds- had decided "to go into banking." ${ }^{49}$

Thus, the Dubuque Harbor Company, founded ostensibly to benefit from the appreciation in land values generated by the building of the railroad, and thus supported entirely by local capital and land and immune to outside liquidation pressure, now stood as the financial lender of last resort to save the Dubuque and Pacific Railroad and the entire beleaguered booster system. Constructed to promote the economic development of Dubuque, the booster system now struggled to save the city's economy. Most Dubuquers-even the Dubuque Express and Herald, which opposed banking on principle "in all its forms"supported issuing currency because it seemed the only way to "save the business community from ruin and thousands of

49. Minutes, Board of Directors, Dubuque Harbor Company, 5 September and 19 and 22 October 1857; Richard Bonson, Diary, 5 September, 9, 12, 14, 15, 16, 17, 19, 21, 23, 24, and 31 October, and 23 November 1857. 
people from starvation." When the Harbor Company notes were printed and signed by the officers on November 12, the company was besieged by requests for loans in currency. Even Richard Bonson "took one of them today" as payment and then used another to buy something, though he observed that it was the first paper currency he had used in 15 years and feared what the result would be. ${ }^{50}$

Rather than placing the notes into general circulation, the company decided to funnel the notes, as loans, through the hands of many of Dubuque's prominent boosters. The Harbor Company quickly loaned the Dubuque and Pacific Railroad Company $\$ 50,000$, although Bonson feared that they would regret it. Even though Bonson complained that the company, "influenced" by personal feelings and conflicts of interest, was granting loans without proper security or collateral, the directors took care of many of their friends. Taking mortgages or stocks in the Harbor Company or Dubuque and Pacific Railroad Company as security, they loaned $\$ 12,000$ to William G. Stewart (a close friend of Bonson's); $\$ 10,000$ to Major Mobley (whose bank was near collapse); $\$ 10,000$ to Caleb H. Booth and William J. Barney; $\$ 5,000$ (later increased to $\$ 7,000$ ) to George Wallace Jones; $\$ 2,500$ to James Huff; $\$ 1,000$ to Dennis Mahony (which allowed him to continue publishing); and $\$ 500$ to J. D. Bush. Bonson, even after all his objections, took $\$ 6,000$. Within days the company's directors had loaned $\$ 46,000$ on top of the $\$ 50,000$ loaned to the Dubuque and Pacific, for a total of $\$ 96,000$. In providing loans to its directors and their friends with collateral in either the Harbor Company or the Dubuque and Pacific Railroad Company, the directors allowed their friends to pay some of their debts in order to save themselves. On November 21, the company then put thousands more notes into general circulation. A few days later, on Bonson's motion, the Dubuque Harbor Company decided to limit its loans to $\$ 150,000 .^{51}$

50. Dubuque Express and Herald, 28 October 1857; Richard Bonson, Diary, 20 October and 12 and 13 November 1857.

51. Richard Bonson, Diary 4, 13, 16, 18, 20, 24, and 27 November 1857; Minutes, Board of Directors, Dubuque Harbor Company, 13, 14, 19, 20, 23, and 27 November and 1 December 1857. 
The economic vise tightening around the city was paralleled by the collapse of George Wallace Jones's political power. His need for relief and his use of his house as collateral signaled his declining power. Jones faced a growing coalition of opponents. Anti-Nebraska factions led by Ben Samuels and Lincoln Clark took the rise of the Republican Party in Iowa as a call to break ranks from the Jones regime and join Thomas Wilson's men. In the midst of the economic panic, the Wilson faction's campaign against Jones intensified. Relations between the two increasingly bitter opponents reached a low point when, during a heated discussion "on the street" in Dubuque, Judge Wilson lost his temper and "struck at General Jones with his kaine [sic] and broke it." Although this local version of Preston Brooks's "caning" of Charles Sumner in Congress harmed Wilson's chances, independent Lincoln Clark, Bonson's close friend William Stewart, and Jones's longtime opponent Dennis A. Mahony were nominated and ran for the state legislature. A few months later, the state legislature elected James Grimes, a Republican, instead of Jones, as Iowa's U.S. Senator. With Jones out of the way, numerous Democrats "bolted" and formed new factions. Richard Bonson, feeling the loss of Jones's support, decided to try to go it on his own. Drawing some support from a remnant of the Jones faction, he and William Stewart placed forward an "independent" slate of candidates. Charging that this so-called independent slate acted in the interests of the Dubuque Harbor Company and the Dubuque and Pacific Railroad Company, not of the people, J. B. Dorr and Dennis Mahony led an emerging courthouse clique to oppose them. ${ }^{52}$

Meanwhile, as people began to use the Harbor money to pay bills, meet obligations, and purchase goods, they got some relief from the pressures they were under. On December 3, Richard Bonson thought he might be able to "collect my debts with it," and thus avoid foreclosing on friends and associates. The following day, while the railroad started paying creditors with Harbor notes, Bonson started paying for lead with them.

52. Lincoln Clark to Julia Clark, 2 January 1856 and 10 February 1857, Lincoln Clark Papers; Richard Bonson, Diary, 19 and 26 August and 12, 13, 14, 15, and 21 September 1857, 23 and 27 September and 3 and 11 October 1859; Dubuque Express and Herald, 13, 22, 23, and 29 September 1859. 
Lincoln Clark accepted and began using them to meet some of his obligations. Dennis Mahony was able to continue publishing his newspaper. William J. Barney and Company, pressed to the wall, "very short in everything" and not "able in some cases to pay deposits in currency similar to that deposited," were able to meet their obligations and protect their assets by paying out "Dubuque Harbor money." ${ }^{\prime 53}$ Thus they survived.

But even as the Harbor Company currency seemed to create some breathing room, the intense pressure on the company to issue still more indicated how many Dubuquers had reached desperate straits and were yet to be helped by the circulation. Other companies, sensing the pressure, recognized the potential returns on issuing notes. After all, since notes usually depreciated, a note issued for one dollar and bought back several months later at 75 cents represented a 25 percent return for the company. Following the lead of the Dubuque and Pacific Railroad, the Dubuque and Western Railroad issued "construction bonds" to pay workers and creditors. In December they began issuing notes, signed by Lucius Langworthy, and continued to do so through March 1858. In November the Harbor Improvement Company, also funded by the Langworthys, began issuing notes. The Dubuque Central Improvement Company issued its own notes in January 1858. Meanwhile, city scrip still circulated. Within several weeks, therefore, a local economy that had been starved for cash in October had a city scrip and five circulating currencies backed by local companies. Although such confusion did not prevent locals from trading and satisfying many obligations, they could not use any local currency to meet regional or national obligations. Outside pressure, therefore, still threatened the entire economy. ${ }^{54}$

These regional pressures were highlighted on December 5, 1857, when Dubuque residents awoke to the shocking news that Major Mobley's bank had closed its doors. Mobley's failure sent

53. Richard Bonson, Diary, 3 and 4 December 1857; Lincoln Clark to Julia Clark, 28 January and 1 and 18 February 1858, Lincoln Clark Papers; Iowa Credit Report Ledger 31, R. G. Dun and Company Collection.

54. Richard Bonson, Diary, 2 December 1857; Dubuque Express and Herald, 4 and 18 November 1857; Minutes, Dubuque City Council, 26 October and 19 November 1857 and 1 February 1858. 


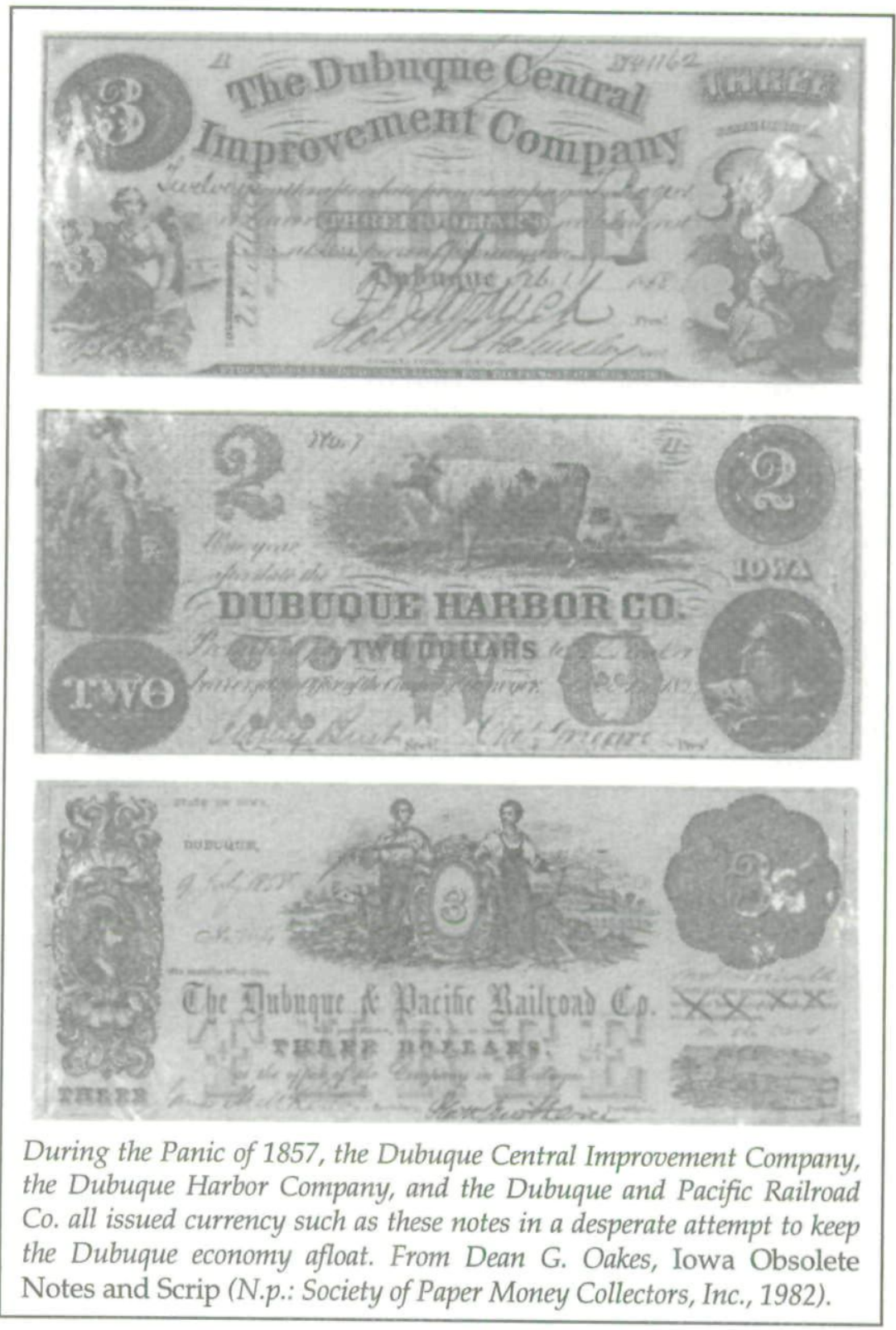

shock waves through the beleaguered town. Richard Bonson, hearing the news, remarked that "everyone feels bad about it." Some company members were so afraid that they "feel like 
holding on a while about putting out any more notes." Jane Taylor, writing to her son John at the Nashville Military Academy, considered the news noteworthy enough to report.

Major Mobley has struggled along with his business difficulties until yesterday when he closed his doors. Everybody feels a great deal of sympathy for him as he is a man very much respected for his kind heart and integrity of character. There have been several more assignments during the past week, among which Stanton and Morgan and Quigley and brothers. Your father thinks they will get through by the utmost economy and vigilance, but, of course, they are making nothing, only buying to sell something from what has already been accumulated and save a business reputation. ${ }^{55}$

As more and more businesses failed and individuals were forced into bankruptcy and liquidation, hundreds more drifted toward ruin. Continuing pressures from outside creditors compelled local creditors to lean more heavily on local debtors. Feeling intense pressure, local citizens called a public meeting to implore the Harbor Company to "provide for the redemption of our post-notes at Chicago and St. Louis." H. L. Stout responded that they could not. The Dubuque Express and Herald urged townspeople to accept the harbor money at par to "establish a confidence in the country" and argued that if "eastern creditors" would "take produce in payment of their debts, the demand for eastern exchange will abate, and the commercial community will be relieved." By year's end, even as, in Bonson's estimation, the "Harbor money [was] beginning to pass some better," scores of businesses had failed and hundreds of individuals found themselves completely ruined, forced to the wall, or encumbered by obligations they could not meet. One ruined bank president, perhaps Major Mobley, caught the sense of shame and humiliation that swept through Dubuque by commenting, in regards to the 1857 season, that "the bottom fell out, and every one was left financially without even a fig-leaf. ${ }^{156}$

55. Richard Bonson, Diary, 5 December 1857; Jane Taylor to John Taylor, 7 December 1857, John W. Taylor Collection; Conzett, "My Recollections of Dubuque," 248.

56. Richard Bonson, Diary, 14 and 31 December 1857; Minutes, Board of Directors, Dubuque Harbor Company, 14 December 1857; Dubuque Express and Herald, 16 December 1857; History of Dubuque County, 531-32. 
AT THE BEGINNING OF 1858, as "money matters" seemed to be "coming to a crisis," nearly everyone in town, save perhaps for the Langworthys and Richard Bonson, found themselves in predicaments similar to those felt by Lincoln Clark, as an individual, and the Dubuque and Pacific Railroad Company, as a corporation. In January Clark saw his problem clearly: "I have a great deal of property and but little money [and] this troubles me." He could not raise money because he could not sell his property for any amount at all. With no cash of any kind, he was unable to pay his mortgage, the interest on his loans, or taxes on his land. Clark later recognized that his "difficulties were created almost wholly in the winter and spring of 1857 just before the dreadful crash burst upon us" when he bought a new house and land "mostly upon payments to be made in the future." This "created all my embarrassments." So, too, the Dubuque and Pacific Railroad was in an "embarrassed condition" for much the same reasons. Because its property was "shingled over with mortgages" and its revenues only paid expenses, it, like everyone else, was stymied by rising taxes and interest that threatened to consume what depreciated assets it had. Even though many individuals and companies in Dubuque managed to escape bankruptcy, most remained encumbered and spent most of 1858,1859 , and even 1860 trying to satisfy, fend off, avoid, or make arrangements with their creditors, or playing one creditor against another, to remain solvent. ${ }^{57}$

By early 1858, however, with several different bank notes in circulation, the game of "swapping cats" or "swapping oats" became harder to sustain. As more people became reluctant to accept any more notes, their value declined. The Dubuque and Pacific Railroad, for example, had used Harbor Company notes to redeem construction notes, issue more construction bonds, and pay off some debts, thus easing both redemption and liquidation pressure against them. In addition, they paid creditors who refused to take Dubuque and Pacific construction bonds with Harbor notes. When, after February, some chose not to ac-

57. Lincoln Clark to Julia Clark, 9 and 28, January, 1, 8, 15, 18, and 25 February, 3 and 7 March 1858, and 6 March 1860, Lincoln Clark Papers; Platt Smith to Robert Benson, 22 February 1858, and Platt Smith to E. F. Bishop, 12 March 1858, Dubuque and Pacific Railroad Company, Out-Letters. 
cept even those, the company began paying creditors in bonds or land deeds. By May 1858, the company, having used most of its notes, and sensing local reluctance to accept any more harbor notes, increasingly used its various Dubuque Harbor notes to settle mostly out-of-town debts in the hinterland. ${ }^{58}$

As the value of the currency began to slip in January and February, and both local and outside creditors stopped accepting it, it was apparent that the "swapping cats" scheme had run its course. In mid-February the Harbor Company began reining in its circulation by buying its own notes with cash, stocks, or securities. Through the late winter and spring directors bought up notes, sometimes with borrowed money, at 70 cents on the dollar, and then burned them. Richard Bonson made his last transaction with the notes-a loan to Thomas Levens, an old friend and fellow miner-on June 3, 1858. Although the notes were gradually pulled out of circulation and fell out of use as other currencies began to trickle back into Dubuque, as late as December 4, 1858, Bonson noted that the company believed that as much as $\$ 21,000$ was still in circulation. Stripped of the temporary cushion of local solvency that the notes provided, Dubuque now stood exposed to one final wrenching cycle of liquidation. That one would push most residents to the wall and compel both the Dubuque Harbor Company and the Dubuque and Pacific Railroad to engage in one last effort to save themselves, as well as the city of Dubuque, from insolvency, default, and ruin. ${ }^{59}$

BY MARCH 1858, the Dubuque and Pacific Railroad was again desperate, unable to meet any of its obligations. Fearing the worst yet again, the directors sent Caleb Booth to New York to

58. Dubuque Express and Herald, 16 December 1857; Milo Quaife, ed., The Early Day of Rock Island and Davenport: The Narratives of J. W. Spencer and J. M. D. Burrows (Chicago, 1942), 253; Octave Thanet [Alice French], Otto the Knight and other Trans-Mississippi Stories (Boston, 1891), 105; Platt Smith to E. F. Bishop, 12 March 1858, J. M. McKinley to Messrs. Wood, Light, and Company, 15 July 1858, J. M. McKinley to Matthew Burnell, 11 May 1858, and James McKinley to W. J. Ackley, 1 June 1858, Dubuque and Pacific Railroad Company, Out-Letters. 59. Richard Bonson, Diary, 27 January, 4, 6, and 13 February, 17, 19, 20, 22, and 24 April, 3 and 17 June, and 4 December 1858. 
try to free some assets from the trustees in New York, but to no avail. They also asked the state of Iowa to bail them out, but for political reasons were refused. When the Langworthys refused to help them, Platt Smith vented his frustration:

Several persons concerned in the Dubuque Western Railroad are very shallow, egotistical, windy characters who parade their full power before the public in a very disgusting manner. To have them talk, one would suppose that Dubuque was the only place on earth, and that they constituted Dubuque; at any rate, if there was anything more than what is comprehended in Dubuque it would be merely an outside belt inhabited by outside barbarians who owed tribute to and derived their light and knowledge from this great center. I am sorry to say that a great many very sensible persons with whom they have here to fore had intimate relations, residing 40 or 50 miles from this place, are much disgusted with the very injudicious course which has been pursued by some of our narrowminded and egotistical citizens. ${ }^{60}$

By summer's end the Dubuque and Pacific and other debtors pleaded with creditors not to pursue a "legal suit" that would only "prevent us from raising money to disembarrass ourselves." In late July, Jesse Farley went to New York yet again to try to sort out some way of satisfying creditors. ${ }^{61}$

At that point Richard Bonson, a stockholder in the railroad as well as a director of the Dubuque Harbor Company with interest in saving the railroad to maintain the assets of the Harbor Company, allowed himself to be elected a director of the Dubuque and Pacific Railroad. What he found shocked him. The company was being strangled by a tightening noose of rising costs and overdue interest and taxes in the face of declining revenues, depreciating land values, devaluing construction bonds, sparse stock sales, and no subscriptions. By year's end, it was apparent that the company would be unable to pay the Harbor Company debt, impairing that company's ability to meet its obligations. As Bonson had feared, and as director on both com-

60. Platt Smith to John E. Goodman, 10 May 1858, Dubuque and Pacific Railroad, Out-Letters.

61. Platt Smith to Messrs. Cook Bros., 19 July 1858, and Platt Smith to M. K. Jesup, 25 July 1858, Dubuque and Pacific Railroad, Out-Letters; Richard Bonson, Diary, 26 July 1858. 
pany boards he could now easily see, the insolvency of the railroad was dragging down the Harbor Company, and the two together would threaten the total collapse of Dubuque's economy. ${ }^{62}$

Hard businessman that he was, Bonson concluded that only a change in management would save the road. Solon Langworthy agreed. The "railroad interests" of Dubuque were "entirely stopped," he observed, and "a change in the officers of the road" was the only "means of restoring the credit of the road." So too the New York trustees argued that because the "road does not pay," it was "desirable to have a better and honester President and Directors in their stead." True to their word, in spring 1859 they forced out the current directors, fired the contractors, installed men they trusted more, and began selling lands to accumulate capital. By that fall, the local directors, all feeling "tolerable flat about railroad matters," "hope[d] for the best" but saw little point in meeting as they waited powerless for the final drama to play out. It ended in May 1860 when New York trustee Herman Gelpcke came to Dubuque, took over the railroad, and relieved local directors of their management roles. On August 7, 1860, the local directors "agreed to turn over the roade [sic] to the trustees" without a fight. Richard Bonson remarked, "it may be a bitter pill but it is the best we could posibily [sic] have done-think it will answer." The local directors, now essentially irrelevant, did not meet again until February 1861, at which time they considered electing Bonson a director again, but he saw no point in it and declined. ${ }^{63}$

Gelpcke, as president of the Dubuque and Pacific Railroad, also purchased the Dubuque and Western Railroad, foreclosed on its debt to the Dubuque and Pacific, and then foreclosed on its creditors "in such a manner as to cut off all the other bondholders and stock holders." By year's end, the Langworthys sued Gelpcke for some share of the proceeds, and a compromise

62. Richard Bonson, Diary, 7, 25, and 28 June 1858 and 26 January 1859; Minutes, Board of Directors, Dubuque Harbor Company, 4 December 1858.

63. Solon Langworthy, Diary, 16 April 1859, 1 and 21 November and 1 December 1860; Richard Bonson, Diary, 7, 25, and 28 June 1858, 26 January, 3, 4, 6, 8, $11,14,15$, and 17 June, 14 and 27 October, and 22 and 29 November 1859, 11 and 25 January, 11 February, 28, 29, and 31 May, 5 June, and 7 August 1860, 4 and 11 February 1861. 
was apparently reached. With the outbreak of Civil War two months later, railroad construction stopped for four years, and management quietly closed out both the Dubuque and Western and the Dubuque and Pacific Railroads, reorganizing the latter as the Dubuque and Sioux City Railroad. Its land grant remained intact, and Platt Smith and Caleb Booth were retained to operate the railroad. ${ }^{64}$

The experience of the Dubuque Harbor Company ended with much the same result in mid-1859. Badly hampered by its outstanding loan to the Dubuque and Pacific Railroad, the locally owned company tried several ways to get some of its investment back. Unwilling to accept any assets of the railroad company and unable to acquire enough from the directors through an assessment, the Dubuque Harbor Company could not pay its bills or redeem its last outstanding currency, leaving everyone at year's end "down upon the railroad company about the debt due them." The directors had few choices left. They cut costs, suspended salaries, stopped improvement projects, and redeemed what notes they could. Bonson was "out of all respect" for the directors, believing they were all "poor businessmen." He reported simply that "the harbor is in debt and cannot pay." As interest payments and overdue taxes rose, the company finally decided to cash out. In 1859 it sold its collateral of railroad bonds at lower and lower prices, until by early summer 1860 it had paid all of its debts. Richard Bonson and H. L. Stout were appointed agents simply to settle and collect debts. When that was done, they did no business that year or the next. After that, the directors met briefly twice a year; the minute book reports simply that "there being no other business," they adjourned. So as early as 1861, the Harbor Company, though still a legal corporation, was "quiescent so far as public affairs are concerned." It engaged primarily in managing its books "preparatory to final exit from before the public gaze," which did not finally take place until February $1,1882 .^{6 .}$

64. Dubuque and Pacific Railroad, Out-Letters, 1864-1867.

65. Richard Bonson, Diary, 18 December 1858, 14 and 22 January, 3 June, and 7, 10, 17, and 21 December 1859, 2 January, 12 May, and 15 June 1860; Minutes, Board of Directors, Dubuque Harbor Company, 29 September 1858, 14 and 22 
In contrast, the Dubuque Central Improvement Company had issued notes directly endorsed by merchants on the back of the notes, confirming that they would redeem all the paper money at par. But "when the crash came," as one observer recalled, "the money was not worth the paper it was printed on." The merchants who had endorsed the notes "had to redeem them at par as long as any were outstanding, even after they were not worth ten cents on the dollar. It caused the failure of many of the stockholders, merchants, and brokers, and even the poor laborer." Jesse P. Farley, Robert Waples, Frederick Bissell, Caleb Booth, Thomas Rogers, Ben Samuels, and O. P. Shiras, who had no connection with the Dubuque and Pacific Railroad, were among the merchants hit hardest by the depreciation of the notes and the failure of the company. By spring 1859, the Central Company was in "default" and returning land to the city. ${ }^{66}$

As the panic and its aftermath eroded the structure of the booster system, the burden of interest payments on the bonds the city government had issued to support the railroads, delinquent taxes unpaid, and declining revenues tightened the economic noose around the city government. With the railroad and improvement companies already in disarray, the third and final bulwark of the booster ethos was badly undermined. In mid1858 a lawsuit by Herman Gelpcke forced the city government to stop issuing any more railroad bonds. At the same time, the city "defaulted" on promises to issue bonds for new railroads to the north and northwest. As government budgets contracted, government policy retrenched to municipal maintenance and services. ${ }^{67}$

THE CRASH OF 1857 marked a watershed in the political, economic, and social history of Dubuque and scores of towns like it across the West. Founded a generation before, they had

January and 10 and 17 December 1859, 6, 12, and 14 January 1860, 15 January 1865, 8 July 1881, and 28 January 1882; History of Dubuque County, 532.

66. Conzett, "My Recollections of Dubuque," 205; Minutes, Dubuque City Council, 10 and 21 March 1859.

67. Minutes, Dubuque City Council, 4 October 1858. 
slowly emerged as central places for their surrounding regions. Boosters firmly believed they could foster local growth and development and maintain control over it by husbanding and developing their local resources and encouraging townspeople to do the same. Optimistic that such a policy promised their city a future as a regional entrepôt, boosters threw themselves into speculative improvements, taking on a heavy public and private debt and investing deeply in land during the boom of the 1850s. In the process, they constructed the booster system as a framework for public policy-patched together by a merging of public and private capital through negotiations and exchanges between untested local corporations. They did this on the shaky foundation of a complex social structure divided into various factions. Convinced that their future lay in investing their own capital and supporting each other, they failed to consider the implications of encumbering local capital to debt from outside investors. In the enthusiasm of the boom, they spread their investments across multiple directorates. Their objectivity was clouded by conflicts of interest and personal friendships. Relying only on handshakes and promises, they supported each other in projects beyond their capital base. For a while after outside pressure hit the local economy, Dubuque boosters successfully used the structure of interlocking directorates and evasive currency-swapping maneuvers to delay the final reckoning. But this worked only for so long. In the wake of the financial crisis of 1857, banks, mercantile houses, manufactories, and improvement companies fell, hundreds went bankrupt, thousands were thrown out of work, and the city government and countless residents were "haunted" for years by debt.

By liquidating a decade of investment in farms, businesses, and railroads, the Panic of 1857 brought regional development to a halt until after the Civil War. As Platt Smith feared, not only in Dubuque but across the region construction stopped, trade declined, population dropped, and thousands migrated west or east in search of new opportunities. Whether they stayed or left, the lives of all of the city's residents were forever changed. The crisis also disrupted local social development and discredited the booster ideology. The Panic of 1857 thus marked a turning point in local and regional life. It would affect subsequent ur- 
ban, social, and cultural development in the Midwest and West for a generation. ${ }^{68}$

For those who stayed, the Dubuque of 1861 would be a new place. No longer a separate world shaped by boosters' dreams, Dubuque and other towns like it were but points in a regional system increasingly dominated by Chicago. These places faced a slow-growth economy and all the limitations on social, economic, and cultural opportunity that implied. Those who were left without anything found no future in such places. For them, the "shattered dreams" of the 1850s cast a shadow of stagnation and decline that lingered for years. ${ }^{69}$

A core of boosters did remain in Dubuque, in spite of everything. George Wallace Jones, his career in the Senate over, became a minister to Columbia until he was recalled and arrested for sedition in 1862. He was later exonerated and returned to Dubuque to live out his days supported by friends until his death in 1896. Jones survived his adversary Thomas S. Wilson, who remained active in the bar and then in the memorial culture of the local bar and fraternal organizations until his death in 1894. Jones's friend Warner Lewis was "ruined" by the panic and, because of his southern sympathies, by the Civil War (his son fought for the Confederacy). Lewis lived out his days as county recorder, a position his friends acquired for him out of sympathy. James and Lucius Langworthy both died in early 1865. Solon and Edward, the only Langworthy brothers to survive the war years, lived into the 1880 s, remained active in business, and cultivated an elite provincial social life, apparently oblivious that their world based on landed wealth was disappearing. Richard Bonson, Platt Smith, Caleb Booth, H. L. Stout, and Jesse Farley all pursued increasingly local careers

68. James L. Huston, The Panic of 1857 and the Coming of the Civil War (Baton Rouge, LA, 1987), 14-34; Elliott West, The Contested Plains: Indians, Goldseekers, and the Rush to Colorado (Lawrence, KS, 1998), 100, 115; Ronald M. Hubbs, "No Cash, No Credit, No Jobs: St. Paul and the Panic of 1857," Ramsey County History 25 (1990), 20-27.

69. Huston, The Panic of 1857, 24; Franc B. Wilkie, Personal Reminiscences of Thirty-Five Years of Journalism (Chicago, 1891), 31; Russell L. Johnson, "The Civil War Generation: Military Service and Mobility in Dubuque, Iowa, 1860 1870," Journal of Social History 32 (1999), 793; Ross, "Cases of Shattered Dreams," 201-39. 
with the Dubuque and Sioux City Railroad, a regional manifestation of the Dubuque and Pacific Railroad that operated in the shadow of the Illinois Central system. The Dubuque and Sioux City Railroad, reorganized in 1864 under the control of the Illinois Central, became an institutional vestige of the old local elite, with a historical connection to Iowans who had gone to Washington, D.C., or who became members of a regional bar, railroad, and business elite in the 1870s. Booth, Stout, and Farley remained active and continued as the local operators, defending it from a number of takeover attempts through legal efforts through 1887. In the course of fighting, they gradually recognized how powerless they were, as a small company in a world of systems run from New York and Chicago. Increasingly convinced that small and locally owned was better, they articulated a viewpoint in response to the railroads that would contribute to the development of a populist small-town ideology across the Midwest during the $1870 \mathrm{~s}$ and $1880 \mathrm{~s}^{70}$

Most Dubuque boosters of the 1850s left the city in search of a new start. William Barney, Lincoln Clark, and many others migrated to Chicago. Clark struggled unsuccessfully for a few years and then retired to Massachusetts. Barney continued in the law and the land business; he also remained active in the operation of the Dubuque and Sioux City Railroad. Like George Wallace Jones, Dennis A. Mahony was arrested for sedition and imprisoned-a story he told in his wartime book, The Prisoner of State. Upon his release, Mahony returned to Dubuque, then moved for a time to St. Louis where he worked as a newspaper editor. When he died in 1879, he was living again in Dubuque. Franc B. Wilkie, who arrived destitute from Davenport to work with Mahony in 1858, followed the Dubuque boys into the war in Missouri, became a war correspondent first for the New York Times and then for the Chicago Times. After the war, Wilkie

70. Parish, George Wallace Jones, 293-303; M. M. Hoffman, "The Wilsons of Dubuque," Annals of Iowa 21 (1938), 322-34; Theodore S. Parvin, "Thomas S. Wilson," Iowa Historical Record 40 (1895), 193-204; Platt Smith to C. B. Raymond, 28 January 1858, and Platt Smith to Robert Benson, 22 February 1858, Dubuque and Pacific Railroad, Out-Letters; Report of the Dubuque and Pacific Railroad Company, 1 January 1858 (Dubuque, 1858), 15-19; New York Office, Dubuque and Pacific Railroad, In-Letters, October 1867-1887; Conzett, "My Recollections of Dubuque," 231; History of Dubuque County, 828-32, 873-75. 
moved to Chicago and became a prominent newspaperman and writer. Major Richard Mobley, destitute from his failure in 1857, moved to Washington and held a series of modest government positions, becoming part of the "Iowa Colony" there until his return home in 1878 . William Vandever, elected to Congress in the Republican upsurge of 1858 , took a company of Dubuque men into the war and rose through the ranks to brigadiergeneral. Like so many Iowans, he returned to find limited opportunities in the "old town," became a "railroad man," served in the Bureau of Indian Affairs in New Mexico and Arizona territories, and entered the mining business in New York before migrating to Ventura County, California, in the 1870 s. He was elected to Congress in the $1880 \mathrm{~s}^{71}$

Whether they stayed or left, each member of the booster elite who had experienced the frenetic rise of the "palmy days" of the 1850s and then the panic and recession of 1857 understood with each passing year the growing distance between their city and the "way of the town" they had lived in before the Civil War. In the years to come they would play a central role in constructing a new national middle class in Gilded Age America.

71. Lincoln Clark Papers; New York Office, Dubuque and Pacific Railroad, InLetters, October 1867-1887; D. A. Mahony, The Prisoner of State (New York, 1863); Wilkie, Personal Reminiscences; Franc B. Wilkie, The Iowa First: Letters from the War (Dubuque, 1861); Richard Martin, "First Regiment Iowa Volunteers," Palimpsest 46 (1965), 5-6; Helen Wulkow, "Dubuque in the Civil War Period," (Ph.D. diss., Northwestern University, 1941); Thomas W. Hurm, "Dennis Mahony, Iowa Copperhead" (Ph.D. diss., Catholic University, 1966); Stiles, Recollections and Sketches, 819, 132-34; Conzett, "My Recollections of Dubuque," 248; Childs, History of Dubuque County, 850; William Vandever Papers, University of Dubuque. 
Copyright of Annals of Iowa is the property of State of Iowa, by \& through the State Historical Society of Iowa and its content may not be copied or emailed to multiple sites or posted to a listserv without the copyright holder's express written permission. However, users may print, download, or email articles for individual use. 